NBER WORKING PAPER SERIES

\title{
SCIENTIFIC PRODUCTIVITY AND ACADEMIC PROMOTION: A STUDY ON FRENCH AND ITALIAN PHYSICISTS
}

\author{
Francesco Lissoni \\ Jacques Mairesse \\ Fabio Montobbio \\ Michele Pezzoni \\ Working Paper 16341 \\ http://www.nber.org/papers/w16341 \\ NATIONAL BUREAU OF ECONOMIC RESEARCH \\ 1050 Massachusetts Avenue \\ Cambridge, MA 02138 \\ September 2010
}

Early drafts of the paper benefitted from many comments by three anonymous referees and from remarks by participants to several CID workshops and to the DIME conference on "Knowledge in space and time: economic and policy implications of the Knowledge-based economy" (Strasbourg, April 2008); the BRICK-DIME workshop on "The Organisation, Economics and Policy of Academic Research" (Moncalieri, July 2008); the NBER Productivity Seminar (Cambridge MA, March 2009). We are particularly grateful to Pierre Azoulay and Paula Stephan stimulating suggestions. This work was supported by the Italian Ministry of Education [FIRB to J.M.]; European Cooperation in Science and Technology [IS0604 to M.P.]; European Commission [FP6-043345 to F.L., FP6-043345 to F.M.] The views expressed herein are those of the authors and do not necessarily reflect the views of the National Bureau of Economic Research.

NBER working papers are circulated for discussion and comment purposes. They have not been peerreviewed or been subject to the review by the NBER Board of Directors that accompanies official NBER publications.

(C) 2010 by Francesco Lissoni, Jacques Mairesse, Fabio Montobbio, and Michele Pezzoni. All rights reserved. Short sections of text, not to exceed two paragraphs, may be quoted without explicit permission provided that full credit, including $(\subset$ notice, is given to the source. 
Scientific Productivity and Academic Promotion: A Study on French and Italian Physicists Francesco Lissoni, Jacques Mairesse, Fabio Montobbio, and Michele Pezzoni

NBER Working Paper No. 16341

September 2010

JEL No. I23,I28,J24,J45,O31

\begin{abstract}
The paper examines the determinants of scientific productivity (number of articles and journals' impact factor) for a panel of about 3600 French and Italian academic physicists active in 2004-05. Endogeneity problems concerning promotion and productivity are addressed by specifying a generalized Tobit model, in which a selection probit equation accounts for the individual scientist's probability of promotion to her present rank, and a productivity regression estimates the effects of age, gender, cohort of entry, and collaboration characteristics, conditional on the scientist's rank. We find that the size and international nature of collaborative projects and co-authors' past productivity have very significant impacts on current productivity, while age and gender, and past productivity are also influential determinants of both productivity and probability of promotion. Furthermore we show that the stop-and-go policies of recruitment and promotion, typical of the Italian and French centralized academic systems of governance, can leave significant long-lasting cohort effects on research productivity.
\end{abstract}

Francesco Lissoni

DIMI-Università di Brescia

via Branze 38 - 25123 Brescia

Italy

and KITES-Università Bocconi

lissoni@ing.unibs.it

Jacques Mairesse

CREST-INSEE

15, Boulevard Gabriel PERI

92245 MALAKOFF CEDEX

FRANCE

and UNU-MERIT (Maastricht University)

and also NBER

mairesse@ensae.fr
Fabio Montobbio

Insubria University

Via Montegeneroso 71

21100 Varese

Italy

and KITES-Università Bocconi

fabio.montobbio@unibocconi.it

Michele Pezzoni

Dipartimento di Ingegneria Gestionale

Università di Bergamo

viale Marconi 5 - 24044 Dalmine

Italy

and KITES-Università Bocconi

michele.pezzoni@unibg.it 


\section{Introduction and overview}

Countries exhibit very substantial differences in their scientific productivity as well as in the institutional settings of their research activities (May, 1997; King, 2004). However, most of the available studies on academic scientists' productivity and careers are based upon US data, and their theoretical insights and policy implications take for granted the institutional characteristics of US universities (Long, 1978; Allison and Long, 1990; Levin and Stephan, 1991; Lee and Bozeman, 2005). Little is known in fact on the determinants of academic scientists' productivity in Europe. European university systems differ substantially both from their US counterparts and among themselves, the most important differences being related to the degree of autonomy of universities, the size and flexibility of the academic job market, and the relative weight and quality of universities and public research organizations (PROs) within the national science system.

In this paper we study various determinants of careers and scientific productivity of academic physicists in France and Italy, by taking explicitly into consideration the institutional context of the two countries. In both France and Italy, universities have very limited autonomy and compete for human and financial resources with large PROs (especially important in France). Their tenured staff are civil servants recruited and promoted through centralized procedures controlled by the State. This centralization tends to originate highly irregular recruitment and promotion "waves", such that career opportunities may be absent for long intervals of time, and then appear all of a sudden as a 
consequence of a policy decision. We expect such irregularities to result in longlasting cohort effects on productivity, which we wish to compare with other productivity determinants found to be significant by US-based studies.

We thus investigate the effects of age, gender, cohort of entry and past productivity both on individual scientists' current productivity and on their career progress. We also consider the role of size and nature (international vs. national) of research projects as well as the influence of co-authors' productivity. We base our analysis upon a panel of about 3600 academic physicists, with the exception of nuclear and astro-physicists, all of them active in academic year 200405. Our productivity measures, both in terms of "quantity" and of "quality", derive from information from the ISI-Web of Science pertaining to a set of some 360 journals covering most specialized journals in physics with some reputation (namely, with at least a five-year average impact factor of 0.5).

We consider five productivity regressions, one for each main position in the academic ranking of the two countries, from assistant to full professor: precisely Maitre de Conference (MCF) and Professor (PR) in France, and Ricercatore Universitario (RU), Professore Associato (PA) and Professore Ordinario (PO) in Italy. We also specify three selection probit equations accounting for the individual scientist's probability of promotion from respectively MCF to PR, RU to PA, and PA to PO. The three productivity regressions for PR, PA and PO are estimated jointly with the three corresponding promotion equations as a generalized Tobit model by means of Heckman two-step method. Estimating a 
productivity regression for each rank, and jointly with a promotion probit equation for professors helps in controlling for unobserved individual heterogeneity across ranks and in correcting for selectivity in promotion to professorship. We also take care of individual heterogeneity among individual physicists by including past productivity variables in all equations: three year average lagged productivity in the promotion probit equations, and average productivity before recruitment (for MCF and RU) or promotion (for PR, PA and PO) in the productivity regressions.

As expected from the background literature, our results confirm the existence of age and gender effects both on the probability to be promoted and on productivity conditional on academic rank, although with some differences between ranks and countries. They also confirm that physicists' own past productivity has very significant positive impacts on promotion probability and current productivity. We find that the size and international nature of collaborative projects, as well as co-authors' past productivity, are influential determinants of current productivity. Finally, we provide significant evidence that the physicists recruited or promoted in 1980 in Italy and in 1985 in France (when massive recruitment and promotion waves took place after several years with limited career opportunities) are on average less productive than the other physicists, showing the damaging and long-lasting effects of the stops-and-goes in recruitment and promotion policies typical of the two centralized academic systems. 
The remainder of the paper is organized as follows. In section 2 we very briefly outline the background literature, and in section 3 we present at some length the institutional features and relevant historical developments of the French and Italian academic systems in the past 30 years. In section 4 we explain our data and justify our choice of econometric specification, and in section 5 we comment in detail our results. Section 6 concludes.

\section{Background literature}

Interest in the determinants of individual scientists' productivity goes back to the XIX century ${ }^{1}$. From the very start, enquiries on scientific productivity were meant to cast light on a two separate issues: the soundness of eugenic principles proposed by Sir Francis Galton, whose studies on the "hereditary genius" had been largely based on the demographics of "eminent men of science"; and the impact of academic institutional arrangements and incentive schemes on a country's scientific performance, as measured by the number of outstanding scientists from that country (Cattell, 1903; Godin, 2006; Godin 2007)². Both the

\footnotetext{
${ }^{1}$ James Cattell published in 1903 the first systematic data collection on scientific papers per author and provided strong evidence of the existence of large differences across individuals, a result later systematized by Alfred Lotka's well-known “power law”(Lotka, 1926).

${ }^{2}$ A third purpose served by these early enquiries was the study of disciplines, from their birth to consolidation. This is still a very much beaten path, although recent studies add to simple paper counts increasingly sophisticated applications of network analysis (Crane, 1972).
} 
issues have been debated ever since and are still present in today's studies, although quite often in a disguised manner.

Since the 1960s, sociologists of science have tested whether increasing returns to scientific reputation and productivity (presently referred to as "Matthew effect") may explain Lotka's law better than the unequal distribution of intelligence in the population (Merton, 1968; Merton, 1988; David 1994). A typical result in this direction has been obtained by Long and Fox (1995), who find that, other things being equal, graduates from prestigious universities have a higher chance to get their first job at institutions in the same league, with substantial advantages in terms of present and future research productivity. As for individual determinants, gender is the one that has attracted most of the attention, with cognitive and genetic explanations of gender differences (as opposed to social ones) being still debated (Etzkowitz et al., 2000; Fox, 1999; Spelke, 2005).

Understanding the relationship between academic institutions, incentive schemes, and scientists' performance has become increasingly important over the last 30 years or so. This surge of interest can be explained by the policy makers' wish to measure and increase the effectiveness of the public funding of science. Leading research universities and scientists, facing possible budget cuts, have also actively lobbied in favour of a higher concentration of resources on the basis of publication- and citation-based indicators of excellence (Graham and Diamond, 1997). 
An important line of research explores the impact of age and tenure on scientists' productivity. In particular, many studies have explored the possibility that individual scientific productivity follows a life cycle: productivity increases when the scientist is young, reaches a peak at/before middle age, and declines afterwards (Levin and Stephan, 1991). At the same time, studies on tenure have tried to clarify whether observable life cycles are due to biological factors or to the incentive structure, such as the reduced "publish-or-perish" pressure on senior scientists with tenured positions. In a rare study on a non-US sample, Turner and Mairesse (2002) find that while promotion has a positive effect on the quantity and quality of publications, the time spent on the same tenured senior position has a negative impact on both variables. They also show that being a member of a highly productive laboratory fuels individual productivity. This confirms that some institutional variables, such as the stratification of universities according to prestige and funding, may generate increasing returns in science.

\section{Recruitment and careers of academic scientists in France and Italy}

Most of the available literature on scientific productivity is based both theoretically and empirically on the US case. This is an important limitation, because the latter is not representative of university systems worldwide ${ }^{3}$. The centrality of universities for public science, the degree of academic job mobility,

\footnotetext{
${ }^{3}$ Noteworthy exceptions are Turner and Mairesse (2002), Bonaccorsi and Daraio (2003), Hall et al.
} (2005), Mairesse and Turner (2006), and Breschi et al. (2007, 2008). 
and the clear stratification of universities according to research intensity are typical characteristics of the USA (Ben-David, 1992; Clark, 1993). In countries such as France and Germany, for example, large public research organizations such as CNRS (Centre National de la Recherche Scientifique) or the Max Plank Institute have been regarded by policy makers as the main pillars of the public research system; Italy also followed this model for many years with CNR (Consiglio Nazionale delle Ricerche).

As for job mobility, we observe that US universities select candidates for professorial jobs in total autonomy, with no control from the central (federal) or state governments. Professors of all ranks are university employees who can bargain for their wages and working conditions on an individual basis; in addition, the existence of a proper academic job market allows scientists with a strong publication record to move across universities in search of better paid or better funded research positions (Ehrenberg et al., 1990). This is hardly the case in France and Italy. In these centralized systems university staffs are considered civil servants, who are employed by the government and selected by commissions of senior peers, chosen by national members of the relevant discipline or nominated by government. In these countries, there is not a strong competition between universities for recruiting or promoting the most promising or productive scientists.

At the same time, strict dependence of universities on government funding (which tend to be highly pro-cyclical) and the frequent reforms of the recruitment 
procedures tend to make career perspectives highly erratic. Italy, for example, has a long history of prolonged periods during which universities did not recruit new scientists, due to funding shortages or ongoing policy revisions, followed by sudden waves of mass recruitment and promotions, often under the political pressure exerted by the large number of scientists seeking a tenured position after many years of temporary contracts.

\subsection{Academic careers in France and Italy}

The French academic system has two main positions: "Maitre de conférence" (MCF; roughly equivalent to the US rank of assistant professor) and "Professeur" (PR). In Italy there are three positions: "Ricercatore universitario" (RU), "Professore Associato" (PA) and "Professore ordinario" (PO). In French physics, MCFs amount to around two thirds of tenured faculty, while in Italy each of the three ranks adds up to around one third of tenured faculty (see figure 1).

\section{[FIGURE 1 ABOUT HERE]}

All positions are tenured, and for all of them the teaching and research duties, as well as the wages, are defined by national laws, with limited possibility of negotiation at the local level. Whatever their rank, academics are classified by the government according to their discipline. Such disciplines act very much as professional guilds, since their members (and not individual universities or 
department) control the recruitment process ${ }^{4}$. Before accessing any of the abovementioned positions (most often RU in Italy and MCF in France) young scientists go through post-doc positions of various lengths. Universities that wish to recruit a young scientist or promote any member of the academic staff are subject to a series of administrative constraints, which limit their freedom to allocate funds to recruitment or career progress in the absence of governmental approval, and require them to follow a set of complex procedures to place a job call and collect the related applications. In addition, the job calls may be suspended by the government at any time for either financial or regulatory reasons, forcing universities to delay their recruitment or promotion plans.

In Italy and France, these constraints have often clashed against an increasing demand for higher education instruction, whose growth was particularly intense in the 1960s and 70s. In those years, both countries answered to the growing number of students of those years by hiring a large number of young assistants with fixed-terms contracts or when tenured weak prospects of promotion (Professori incaricati as well as contrattisti and assegnisti in Italy, and Assistants and Maitres Assistants in France). In early 1980s, two reform acts were passed: law 382 in Italy (in 1980) and the Higher Education Act in France (in 1984). Both laws reformed the recruitment process by introducing the ranking system we

\footnotetext{
${ }^{4}$ Notice also that the US system is openly stratified according to the research $v s$. teaching intensity of institutions. On the contrary, both the Italian and French laws forbid universities to differentiate openly their mission, and to assign different research versus teaching loads to the faculty.
} 
described above, and by changing the hiring rules. At the same time, a number of ad hoc measures were passed along with the new laws, which were meant to allow many professori incaricati and assistants to obtain tenured positions as ricercatori or professori associati in Italy, or maitres de conference in France. In Italy, the ad hoc procedures were merely formal and candidates did not face any selective competition $^{5}$ (Clark, 1977; Moscati, 2001). As a result, in each country there was a massive recruitment wave (respectively in 1980 and 1985), followed by a prolonged period without any recruitment in Italy, and by a sensible decline in recruitment in France. Figures 2 and 3 illustrate this effect for the field of physics: they report the number of scientists - who were on active duty in 2004-05 - by year of recruitment (for RU and $\mathrm{MCF}$ ) or year of last promotion (for those in professorial positions). The 1980 and 1985 entry/promotion peaks are clearly visible.

[FIGURES 2 AND 3 ABOUT HERE]

The 1980 and 1984 laws also had lasting effects on the selection procedures. In Italy, it was established that the promotion to PA and PO had to occur at a national level, for a number of positions issued every other year by the ministry, and managed by a professors' committee whose members were first chosen by all

\footnotetext{
${ }^{5}$ See article 50 and 57 DPR 382/1980 for Italy and article 59 Décret n 84-431 du 6 juin 1984 for France. These laws can be found (in original language) on the following websites: http://www.pd.infn.it/infn ric/GruppiLavoro/Stato Giuridico/Stato\%20Giuridico\%20Universitari DPR382 1980.html and http://www.legifrance.gouv.fr/
} 
peers in each discipline, and then further selected by the ministry. As for RUs, these were selected at the university level by a committee of three among PAs and POs, all appointed by the ministry. Together with the universities' lack of financial autonomy, this highly centralized system soon became responsible for a number of difficulties in speeding up the recruitment process by universities throughout the 1980s and early 1990s (see again Figure 3).

In 1998 a new recruitment system was introduced, which was still in place at the time of our study ${ }^{6}$. The system allows each university to offer new positions by launching its own call for applications (concorso), and to set up an examination committee. All the committee members, however, must belong to the same discipline for which the position is offered and (with the exception of just one member) they are not selected by the university, but elected by all the discipline affiliates at the national level. Nominally, the commission has not the task to pick the most suitable candidate for the university that launched the call (on the basis, for example, of the coincidence of the candidate's and the university's research interests), but the best possible candidate in absolute terms, who should be the one with the best publication record (called "idoneo", which means fit-for-the-job). In principle, if the university does not like this candidate, it can always refuse to nominate him/her and launch a new job call. In practice, most commissions try to

\footnotetext{
${ }^{6}$ While we revised the paper, the Ministry of Education announced a new change in the recruitment laws, which by June 2009, however, had not yet been entirely disclosed to the Parliament.
} 
steer the selection process towards candidates deemed suitable for the university. ${ }^{7}$ Once again the introduction of the new law coincided with a new wave of recruitment; although less dramatic than the 1980 one, this is still visible in Figure 2, in the years between 1999 and 2001.

The French recruitment system is also very centralized and disciplinecentred $^{8}$. Every year, the central government issues a list of vacancies, by discipline and institution, both for the MCF and PR positions. The applicants need first to get a qualification certificate, which is granted by the CNU (Conseil National des Universités) - whose members are partly elected and partly designated by the Ministry of Education. Once obtained, the qualification is valid for four years and the qualified candidates are the only ones who can apply for the vacant positions. Applications will then be examined at the university level, by disciplinary commissions, composed both of local and non-local members ${ }^{9}$.

7 This requires many behind-the-scene manoeuvres by the university, aimed at steering the election of the committee members in favour of friendly candidates. For a more in-depth discussion of this point, and of its consequences for academic careers in Italy, see Pezzoni et al.

${ }^{8}$ In August 2007, the Sarkozy presidency initiated a number of much debated and still on-going reforms which are aimed at giving autonomy to universities by shifting powers and administration of resources from the Ministry to them.

9 These disciplinary commissions are made up of 10 to 20 members, coming both from the discipline or possibly other disciplines in the university, and from the discipline in other universities. These commissions, in which PR and MCF sit in equal number, are elected for 4 years; 
Both the Italian and the French recruitment systems have undergone severe criticism over the years, which resulted in a succession of reforms that shifted the balance of decision power in recruitment matters back and forth between the national and local level (Chevaillier, 2001; Moscati, 2001; Musselin, 2005). None of these reforms, however, has gone as far as to grant universities total freedom in recruitment matters, nor it has diminished much the power of disciplines. More importantly, the procedural uncertainty created by this succession of reforms, combined with repeated cuts in the public spending for universities, has made the recruitment process very irregular over time.

Time irregularities in recruitment and career advancement mechanisms determine the age composition of the academic workforce. Table 1 reports the number of physicists in France and Italy in 2004-05 by rank and decade of birth. As expected, the lower academic ranks are populated by younger scientists in both countries. However, in Italy the top academic rank (PO) is populated by much older scientists than its French equivalent (PR): while in France 19.6\% of the full professors (PR) were born in the 1960s, in Italy the percentage of PO from the same decade is only $2.6 \%$. Although less striking, such differences in age composition hold also for the lower ranks: only 11.6\% of Italian RU were born in the $1970 \mathrm{~s}$, as opposed to $25.0 \%$ of French MCF. This is a very likely consequence of PR in a formation restricted to PR. 
the higher emphasis on seniority-career links in Italy, and of the higher irregularity of the Italian recruitment process.

\section{[TABLE 1 ABOUT HERE]}

Finally, an important institutional feature of both the French and the Italian research systems is the role of large PROs such as CNRS and CNR, respectively. In France, CNRS has been traditionally regarded as the most important actor of the research system (even more so in physics, with the exception of nuclear physics, where that role is contended by CEA, a special agency for atomic energy). As such, it has often out-competed universities in attracting the best and most motivated young scientists, who may perceive the academic position of MCF as overloaded with teaching and administrative duties (not so much the professor's position, which is often targeted by CNRS Chargés de recherche). In Italy, the history of CNR starts similarly to that of CNRS, which indeed was taken as a model for its creation, in the late 1930s. Badly hit by successive budget cuts, the CNR has progressively lost its centrality in the Italian research system, as well as the possibility to offer permanent positions to young scientists. This implies that while French universities have at least one competitor in the academic labour market, Italian universities have none. ${ }^{10}$

\footnotetext{
${ }^{10}$ Note also in France the existence of institutions of higher education called "Grandes Ecoles", such as "Ecole Normale Supérieure" and "Ecole Polytechnique" to cite two oldest and most prestigious ones. They are of very small size compared to universities, but they select excellent students, and have also developed good research activities in the last twenty years.
} 


\subsection{Implications for scientific productivity}

The analysis of the recruitment process in the two countries, and of the relative balance of universities and PROs inside the research system, suggests some observations on the factors affecting scientific productivity. In principle, productivity is a key determinant of career advancement in both countries, at least for senior positions. In a related paper we show that this is indeed the case in France for moves up to PR positions, and in Italy for promotion from RU to PA but less so for promotion from PA to PO (see Pezzoni et al., 2009). As a consequence, other things being equal, we should expect scientists who are currently on higher positions to be more productive than those in lower ones. We should also expect such scientists to exhibit a less pronounced life cycle that is to be highly productive over a longer time spell, and to incur a productivity slowdown at a later age. However, especially for Italy, informal recruitment and promotion practices push in the direction of career by seniority and can give great advantages to local candidates, no matter their productivity. If these effects were dominant, they would significantly weaken the effectiveness of incentives to high productivity.

We also expect to find strong effect for the different years of entry/promotion both in Italy and France, for at least three reasons. First, access to tenured academic positions has increasingly become more difficult over the 1980s and 1990s, so we may presume that scientists who have been recruited over these two decades are more productive than their predecessors. Second, late generations 
of scientists have more international experience and may be expected to find it easier to publish in international journals, which in our data are better represented than national ones. Last, cohorts of scientists recruited en masse over short periods of time (after periods of no recruitment) could be either more productive or less productive than the average. We expect the RU, PA and MCF that entered the university system in 1980 in Italy and 1985 in France (or reached their last academic rank), to be less productive, due to the explicit lack of selective pressure in those two years. We do not have any a priori on the effect of the 1980 and 1985 entry waves on the productivity of scientists in higher positions (PO and PR), which were much less affected by these legislative changes.

We expect productivity to grow over time (calendar years) for at least three reasons. First, both in Italy and in France public research funding has been increasingly distributed on the basis of competitive grants. Second, physics, as any other discipline, has enjoyed decreasing publishing cost, thanks to new procedures and media. Finally, and especially in physics, "big science" and large projects have favoured teamwork, which tends to increase productivity, as measured by publishing (Price and Beaver, 1966) ${ }^{11}$.

${ }^{11}$ : “..It is especially noteworthy that nobody who worked without collaborators or with only one co-author succeeded in producing more than four papers in the five-year period, whereas everybody with more than twelve collaborators produced fourteen or more papers in the same time.." (Price and Beaver, 1966, p. 1014) 
As for gender, no apparent reason exists to think of peculiarities for France and Italy with respect to the US, so we expect to find evidence of a statistically significant gender effect in both countries. Stratification effects may also exist, which we try to capture with information on the affiliation and productivity of our scientists' co-authors.

\section{Data and methods}

\subsection{Data collection and sample}

Our data collection is based on lists of all tenured academics in Italian and French universities, active in academic year 2004/2005, provided by the Ministries of Education of the two countries. The lists classify academics according to their disciplinary affiliation: as indicated in Table 2, the individuals we have selected are those active in all fields of physics, with the exception of astro-physics and nuclear physics ${ }^{12}$. The lists also provide the academics' dates of birth, gender and university, as well as their rank in 2004/2005 and seniority in these ranks. For all

\footnotetext{
${ }^{12}$ Not all the scientists classified in one discipline, in fact, have homogeneous research interests. In addition, it is often the case that some scientists are pushed to join (nominally) the discipline with the highest opportunities of promotion at a given point in time. Face-to-face interviews to Italian physicists show that some nuclear and particle physicists are classified as Fisica Sperimentale (Field FIS/01), which enters our study, instead of being classifies as Fisica Nucleare e Subnucleare (Field FIS/04), which we excluded from our study.
} 
individuals who in 2004/2005 were at the bottom rank of the academic ladder (namely, MCF in France and RU in Italy) we thus know when they were recruited in such position; for all those who in the same year occupied a higher position (PR in France, PA or PO in Italy), we know when they were promoted to such position, but we ignore when they were recruited (as MCF or RU) or first promoted to lesser ranks.

We gathered the information on scientific publications from the ISI Web of Science, from Thompson-Darwent, by matching the surnames and names of the physicists in the ministerial lists with the surnames and initial of names (as coded by ISI) for the authors of all articles published in physics journals going back to 1975. We considered a total of 363 journals classified as mainly physics journals in the ISI records and with a minimum reputation as defined by an average five year impact factor of at least $0.5^{13}$. This list of journals includes all the main international journals specialised in physics and covers well all of its subfields ${ }^{14}$.

\footnotetext{
${ }^{13}$ This means in other words that we excluded the physics journals which have regularly received over a five year period less than 0.5 citations per article. It is also the case that ISI does not cover as well those low reputation journals.

${ }^{14}$ The list of the 20 journals with the larger number of publications in our database is reported in the Appendix Table 6. Interviews with a few physicists have confirmed that no top journals specialised in physics are missing.
} 
Note that we have preferred not to consider generalist journals such as Science or Nature ${ }^{15}$.

\section{[TABLE 2 AND TABLE 3 ABOUT HERE]}

Such a collection strategy is the only one compatible with the publication data gathered from the Web of Science, but it generates problems of homonymy for the small group of physicists with the same surnames and initial of names in the ministerial lists, as well as for those with very common surnames. Ignoring these problems may lead to over-estimating the productivity of these physicists. In other cases homonyms can be found in the original ministerial databases, so that it is impossible to correctly attribute papers. Therefore after some trials we finally

${ }^{15}$ Including generalist journals such as Science and Nature may create even more problems of homonymy than the ones we already have (if there are several "Smith J." in physics, there must plenty when considering all disciplines!). Moreover, we believe there are strong correlations between publishing in specialized journals of good quality and generalist journals of outstanding reputation as Science and Nature. Such generalist journals are few and they are not alternative outlets to specialist physics journals. Top physicists who manage to publish the results of their research in Science and Nature also publish these results in specialized physics journals. In terms of descriptive statistics on "quantity" productivity, the errors we introduce should be more or less negligible. On "quality" productivity, the absence of a few very-high-impact-factor journals such as Science and Nature probably results in chopping up slightly the long tail of the productivity distribution of scientists. In terms of biases in our econometric analysis, one can expect that they will not be sizeable. At the same time, it is very unlikely that a physicist with a small publication record in specialized journals will publish many papers in Science or Nature. 
dropped from our search all homonyms in the ministerial lists and all physicists with an apparent productivity record far too high for being credible, and with quite common surnames. These choices resulted in dropping about 3\% of surnames from the original lists, leaving us with 2151 French physicists (instead of 2211) and 1769 Italians (instead of 1816) ${ }^{16}$. Note also that unless one would think that the spelling of surnames could in some way be related to the scientific productivity, cleaning our study sample from homonyms should not introduce any biases in our econometric results.

Looking at our publications data, we found that about 3\% (52) of the academic physicists in Italy and about 11\% (235) of the French ones have no articles at all before and after recruitment or promotion, and hence a computed zero productivity throughout their observed careers. This significant difference could reflect the French academics' tendency to write much more than Italians also in journals not included in the ISI Web of Science; or by a higher share, in France, of academics involved nearly exclusively in teaching, and/or administrative, advising and consulting activities. Given the lack of specific data for investigating why these "zero-productive" physicists self-select as "non researchers", we

\footnotetext{
${ }^{16}$ Most of the surnames of physicists we discarded are the homonyms in the ministerial lists. Otherwise we have had in fact to discard only 4 names of physicists for France and 2 for Italy because their computed productivity appeared much too large to be credible (with 30 papers or more for at least 10 years!) and they had also widespread surnames (e.g., CHEN or WANG).
} 
thought it was better to simply leave them out from our analysis ${ }^{17}$. Our final study sample is thus made of 1916 French and 1717 Italian academic physicists, for which have a corpus of respectively 44100 and 52919 articles published from 1975 up to 2005 in 363 physics journals. Table 3 gives the number of physicists in France and Italy, active in 2004-2005, by gender and rank in the overall sample (before cleaning) and in our study sample. All the statistics and econometric estimates reported in the following sections of this paper are obtained from our study sample.

\subsection{Specification and estimation problems and solutions}

Our data constitute an unbalanced panel, where individual physicists are observed from year $T_{0}$ to 2005 . For most scientists, year $T_{0}$ coincides with the year of their first recorded publication; alternatively, for the oldest scientists, year $T_{0}$ coincides with 1975, the first year for which any publication record is available in our version of ISI-Web of Science; finally, for the few MCFs and RUs without any recorded publication before their known year of recruitment, $T_{0}$ coincides with the latter.

To assess sensibly and with reasonable confidence the effects of the various determinants of scientific productivity, we have to worry about three major kinds

\footnotetext{
${ }^{17}$ Following a referee's request, we have also replicated our econometric analysis for the sample including the "zero-publications" physicists. Our main results do not change significantly, with the exception of the estimated effects of the 1980 and 1985 entry waves on productivity and promotion, which appear to be stronger. The tables showing these results are available on request.
} 
of interrelated specifications errors: selectivity, endogeneity, and unobserved (correlated) individual heterogeneity. All three are potential sources of estimation biases, as well as of uncertainty regarding the proper meaning and correct interpretation of our estimates. We have tried to take of care of them in a specific and particularly cautious way.

First, we have considered five productivity regressions, both in terms of quantity and quality, one for each position in the academic ranking of the two countries (PR and MCF in France; RU, PA, and PO in Italy); each of these regression exercises is conducted on the subsamples of physicists who had reached these ranks in 2004-2005, restricted to the years after their promotion to the rank. Our estimated impacts of productivity determinants are thus conditional on rank. This helps in controlling for selectivity and endogeneity as well as unobserved heterogeneity of physicists across ranks. We could have tried to estimate only two productivity regressions, one for each country, with rank as an explanatory variable (possibly interacted with other explanatory variables). Even putting aside the difficulty that we do not exactly know the full career history of professors before they were promoted, this would have been a more risky alternative, and a more difficult one since rank is endogenously determined and would have to be instrumented ${ }^{18}$

${ }_{18}$ Of course the interest of this alternative is to be more parsimonious and provide direct estimates of unconditional impacts. We intend to explore it in future work. 
Second, we estimate three selection probit equations accounting for the individual physicist probability of promotion from respectively MCF to PR, RU to PA and PA to PO. These equations are specified jointly with the corresponding productivity regressions as three generalized Tobit models, one for each of the professor ranks. To estimate consistently such Tobit models we have simply relied on Heckman's two-step method, where the probit equation is estimated in the first step, and the productivity equation estimated in the second step including as an additional explanatory variable in the equation the inverse Mill's ratio of the probability of promotion as predicted by the probit equation (Heckman, 1979; Dubin and Rivers, 1989; Wooldridge, 2002) ${ }^{19}$. Besides providing interesting information per se on the determinants of promotion, estimating jointly a model of promotion and productivity helps controlling for selectivity, endogeneity and unobserved heterogeneity. ${ }^{20}$

${ }^{19}$ Note that while the productivity equations are estimated for the professor subsamples restricted to the observations after promotion, the promotion probit equations are estimated on all the observations, both before and after promotion, of these subsamples. We have preferred to use the two-step Heckman method to the maximum likelihood, which encountered in some cases problems of convergence due apparently to our very large number of variables (including in particular in both the promotion and productivity regressions interactions of cohort of entry and year dummies, as explained in the next sub-section).

${ }^{20}$ Note that we might have also considered two probit equations accounting for the individual physicist probability of being recruited as respectively MCF and RU. That was not, however, really possible because of a much too short history of publications before recruitment (or even none) and 
Last, we also control for individual heterogeneity in both the promotion and productivity equations by introducing past productivity variables. In our analysis, individual heterogeneity mainly corresponds to individual characteristics such as ability and motivation. These are not directly observable, but have a major impact on individual performance. In so far as these individual characteristics are mostly permanent, they are bound to be strongly correlated with past productivity. Thus the presence of past productivity in the promotion and current productivity equations will take care of the most likely unobserved heterogeneity biases, if not fully at least to a large extent. ${ }^{21}$

\subsection{The determinants of promotion and scientific productivity}

Table 4 lists all the variables we consider for our econometric exercise. The latter requires estimating two equations: a selection equation in which the dependent variable is promotion of the scientist to the present position (PO, PA, PR), with past scientific productivity as the key explanatory variable; and a

for lack of other background information, such as on graduate studies. Moreover, that also seemed a priori less relevant than concerning promotion to professor.

${ }^{21}$ The standard approach in a panel data setting as ours is to control for permanent unobserved heterogeneity by including fixed individual effects in the equations. Although we may want to go back to this approach in future analysis, our first attempts were not promising. The advantage of our approach here is that past productivity variables largely correct for the likely heterogeneity biases by picking-up the correlated components of individual fixed effects, while being more informative than fixed effects per se and preserving, contrary to them, the relevant cross-sectional information in the data. 
productivity equation in which the dependent variable is productivity, for all scientists in the same position. Each estimation exercise of the productivity equation is run twice, for two different dependent variables that measure respectively the quantity and quality of the scientific productivity of each individual scientist:

- Quantity: $\log (1+$ number of articles in year $t)$

- Quality: $\log (1+$ average 5-year impact factor of journals with articles in year $t)$

[TABLE 4 ABOUT HERE]

We do not correct the number of articles, and the related quality measure, by the number of co-authors of each article; that is, we do not try to capture the individual scientist's contribution to the article. We have two reasons for doing so. First, almost all articles in physics are co-authored, often by quite a large number of scientists. Papers written in isolation or by a few authors may be either theoretical ones or, if applied, they may reflect the isolation of their authors from the rest of the scientific community, rather than a larger individual contribution. Introducing arbitrary corrections according to the number of authors would have meant giving greater weight to theoretical papers or, possibly, to papers by 
peripheral authors. Instead, we control for the productivity of co-authors before $t$, which we expect to be correlated to the number of papers at time $t^{22}$.

The key explanatory variables in both the selection and productivity equation are related to the scientists' age, the historical conditions of the academic labour market at the time of their recruitment or promotion, and time trends in productivity ${ }^{23}$. Additionally, promotion is explained by productivity, which enters the regression through two distinct variables: Quantity flow and Quality flow. These are the average number of papers published by the scientist between $t-4$ and $t-2$, and the related average value of the five year impact factor of journals ${ }^{24}$. Finally, promotion is also a function of Academics per year, which is the number of individuals who achieved promotion in year $t$.

Introducing age, cohort, and historical time in the promotion or the productivity equation creates the identification problem discussed by Hall et al. (2005). In particular, it is impossible to take simultaneously into account age, time

${ }^{22}$ We have also produced a series of ancillary regressions with author-weighted measures of quantity and quality, whose results do not differ substantially from those reported in this paper, and are available on request.

${ }^{23}$ It is common knowledge that bibliometric measures of productivity exhibit an increasing trend over time. Our data do not escape this regularity, both for quantity and quality.

${ }^{24}$ Publications in $t-1$ are excluded because the recruitment procedure (concorso in Italy or concours in France) can take many months, up to one year or so. Therefore, some publications appear after a candidate has filed for the job and are not considered by the commissions relevant for the appointment. 
and birth cohorts, one variable being a linear combination of the other two (age = year - birth cohort). In line with Hall et al. (2005) we attack this problem by using a semi-parametric model in which these effects enter linearly, and are represented by variables the least affected by identification problems.

First, we do not consider birth cohorts, but only entry cohorts. That is, our Cohort dummies refer to the scientists' years of entry in the academic workforce, namely the first year in which the individual scientist published an article or, if the scientist does not have publications before last promotion, the date of last promotion. This is similar to the approach used by Levin and Stephan (1991) which define as cohort the year in which a scientist received her $\mathrm{PhD}$. It also captures more precisely than the year of birth the influence of changes in the importance of research fields or legislation on a cohort's productivity. The entry cohort dummies are interacted with a full set of Period dummies that refer to calendar years; in other words, our semi-parametric model includes a dummy variable for each cohort-period combination (Cohort $\mathrm{x}$ Period).

In addition, we estimate the impact of being recruited or promoted in 1980 in Italy and 1985 in France. We expect scientists belonging to these recruitment waves to display, other things being equal, lower productivity levels than scientists from all other cohorts, due to lack of selective pressure. Notice that the share of scientists recruited/promoted as RU, PA, and PO in 1980 in Italy and as MCF and PR in 1985 in France account for respectively 34\%, 52\%, 19\%, 20\% and $13 \%$ of the observations in the productivity regression samples (see Appendix 
Table 2 and 3), and therefore they represent a substantial share of the academics active in $2005^{25}$. In both the selections and the productivity equation we identify these scientists with the Wave 1980 and Wave 1985 dummy variables. Besides, in the selection equation, we control for the ease of entry into academia by counting, in each year $t$, the number of scientists promoted in that year and still active in the same rank in 2005 (Academics per year).

As for the scientist's age, we address the above-mentioned identification problem by using age groups; more precisely, we introduce in both the selection and the productivity equations five Age dummy variables, representing ten-years age-intervals of our scientists (see Table 4$)^{26}$. Our expectation is to find a negative impact of scientist's age on productivity (Levin and Stephan, 1991; Hall et al., 2005). On the contrary, when considered as a determinant of promotion (selection equation), Age is expected to have a positive impact: the older the scientists, the higher their chances to be promoted (as in Long, 1993).

In both the selection and productivity equations we test for gender effects (Gender $=1$ for women). In our sample, women represent respectively the $23 \%$ and $27 \%$ of the French MCFs and Italian RUs. At the same time they are the $7 \%$ and $6 \%$

\footnotetext{
${ }^{25} \mathrm{It}^{\prime} \mathrm{s}$ worthwhile remarking that we do not have the full career profile of the scientists and therefore we do not know how many PR, PO and PA - that were promoted after 1980 in Italy and after 1984 in France - were previously recruited or promoted in the Wave 1980 and in the Wave 1985. ${ }^{26}$ We have also tried different specifications using directly the age variable and age squared and the results do not change substantially.
} 
of the French PRs and Italian POs. The literature typically indicates that women publish less than men (Levin and Stephan, 1998). However this result often depends on cross-sectional data that cannot control for individual heterogeneity.

Moreover, in both the selection and productivity equations, we control for the scientist's specific research fields through a set of dummies reflecting ministerial classifications of disciplines (Field 28 and Field 30 for France; Field FIS/01, Field FIS/02, and Field FIS/03 for Italy). We expect the probability to be recruited or promoted to be field-specific for two reasons. First, resources to hire new employees are not distributed homogeneously among all the disciplines. Second, some disciplines could be more prolific in terms of new discoveries and research paths, thus attracting more junior scientists. As for productivity, this can also be affected by the scientist's specific field of research, due to differences in the resources needed to produce a paper.

In order to characterize the work environment in the productivity equations, we also control for our scientists' relationship with other members of the scientific community. First, we consider the past productivity of each scientist's co-authors in year $t$ (Co-author's quantity and quality). The co-authors we consider are only those who also belong to our sample (that is, we ignore all co-authors who are neither French nor Italian physicists for which we have no publication data). Their overall Quantity and Quality is calculated over the interval [t-3, $t-1]$ and divided by the number of years in the interval. We expect both variables to bear positive effects on the scientist's productivity, however measured, to the extent that 
working contacts with other productive individuals provide access to knowledge and information ${ }^{27}$.

Second, we consider the size and geographical reach of the projects in which our scientists are involved. We produce four time-varying and mutually exclusive dummy variables that summarize information on the number of coauthors and their addresses, as reported by the ISI publication records (in this case we consider all co-authors, not only the French and Italian scientists) ${ }^{28}$. In order to do so we consider the scientist's publications from $t-3$ to $t-1$. The variable Large Project dummy, then, takes value one if the scientist has at least one article (among this set of lagged publications) with 30 or more authors ${ }^{29}$. All these large projects are international, that is for all papers with 30 or more co-authors, the ISI records

${ }^{27}$ In order to avoid endogeneity problems, we do not consider the co-authors' publication to which the observed scientist also contributed.

${ }^{28}$ The information on affiliation and related addresses provided by ISI is not precise. For each publication, in fact, the authors' names and affiliations are reported in separate fields, with no oneto-one matching between the two. So there is no way to know how many authors of a publication come from a university or research institute among those listed; but only that at least one authors comes for sure from such university or institute.

${ }^{29}$ The share of articles with 30 or more co-authors is higher in Italy (8.57\%) then in France (5.95\%). Appendix Table 4 shows the percentage of large projects in the two countries and the information available about the affiliations (addresses) from the ISI database. Moreover, Appendix Table 5 reports the average number of authors (per article) according to a list of 22 nationalities and PROs. US, German and English scientists are quite frequent co-authors in Large Projects publications, both in Italy and France. 
report several non-Italian and non-French addresses. Alternatively, in case the scientist's lagged publications do not come from any large project, we check whether there is at least one publication resulting from an international project, although of a smaller scale. As a result the Small_project_with_foreign_co-author dummy takes value one if the scientist has no publications with 30 or more authors over $[t-3, t-1]$, but she has at least one publication with at least a foreign coauthor.

A third dummy variable, named Small_project_with_only_national_co-authors signals that none of the co-authors has a foreign affiliation ${ }^{30}$. Finally since in many cases the information on affiliation and addresses reported by ISI is incomplete, we control for the possibility that none of the scientist's articles contains information on its authors' affiliation or addresses (Small_project_with_coauthors_of_unknown_affiliations dummy). Scientists with no publications over [t-3, t-1] constitute the reference case.

In order to capture unobserved heterogeneity in the productivity equations, we control for the scientist's productivity before promotion, that is the yearly average quantity and quality since entry year (Quantity before promotion; Quantity before promotion).

\footnotetext{
${ }^{30}$ This dummy is an approximation since the addresses of the authors are not always reported in the articles.
} 
Finally, we control for problems arising from data design. First, in the productivity equation we deal with the left truncation problem due to the unavailability of information on publications before 1975. To this end, a dummy variable Promotion before 1975 is inserted, which takes value one for scientists who reached the present position before the first year of observation. As for the promotion equation, we simply do not consider observations affected by this problem. Second, we deal with the presence of zero values in all measures of quantity and quality when used as explanatory variables by inserting a number of dummies which take value 1 in case of absence of any publication ${ }^{31}$.

${ }^{31}$ In the promotion equations we include a Zero lagged flow dummy indicating when past quantity and quality-productivity are zeros, while in the productivity equations we include a Zeros before promotion dummy. The reasons for including these two dummies is to allow for some functional form flexibility without imposing that a strict linearity through the value of zero for the effects of the corresponding variables which are measured in terms of $\log (1+x)$ (i.e., respectively the Quantity-productivity lagged flow and Quality-productivity lagged flow variables and the Quantityproductivity before promotion and Quality-productivity before promotion variables). The reason for the inclusion in the productivity equations of the Zeros after promotion dummy is different one. It is to fully abstract from the information that will be conveyed in the estimation of the productivity equations if we did not include it. It is thus simply equivalent to excluding the physicists with only zero publications after promotion from our study sample before estimating these equations. We could have also excluded these few physicists when estimating the promotion equations. Since these physicists have published one or more articles before promotion, we thought, however, better to keep them included (and at the same time to use a study sample based on the information concerning the exact same set of physicists in estimating both types of equations). 
Appendix Tables 1, 2 and 3 report summary statistics for all the regressors, by rank.

\section{Results and discussion}

In what follows we comment separately the results from the estimation of the selection and productivity equations. In the case of RU and MCF we do not see enough history of the individual to explain the promotion with a probit model. For example, many RUs and MCFs published very few or no articles before being promoted to their present rank; and the latter may have been achieved mainly thanks to the candidates' graduate work or educational attainments, which we also do not observe.

\subsection{Promotion equation}

Results from the selection equation for Italy and France are reported in Table 5. Cohort-period interactions are included in the estimation, but not displayed. As expected, the promotion probability of both Italian and French scientists increases with age, which confirms the role of seniority in both academic systems. Note however that for full professors in both countries (PO in Italy and PR in France), the estimated coefficient for Age group 5 (that is, for academics who are more than 60 years old) is smaller than the coefficient for Age group 4. This suggests a non-monotonic effect of seniority on promotion probability

[TABLE 5 ABOUT HERE] 
The positive sign and absolute size of the coefficients for Wave 1980 and Wave 1985 confirm that in those two years a scientist's chances of being promoted were much higher than at any other time in recent history. This result holds despite we also controlled for the (positive) effect of Academics per year on the probability of promotion. For example, the estimated marginal effect for Academics per year in the $\mathrm{PO}$ equation suggests that one more $\mathrm{PO}$ promoted in year $t$ gives any (Italian) candidate to the same position $0.23 \%$ more chances of success $(1.2 \%$ for PA and $0.46 \%$ for PR). On top of this, being a candidate to the same position in 1980 meant a $40 \%$ higher probability of success (38\% also for PA and $18 \%$, in 1985 , for PR). Overall, in 1980, 62 individuals reached the PO position, for a combined increase in the probability of promotion of around 54\%, other things being equal (40\% from the Wave 1980 dummy, plus 62x0.23\% from Academics per year).

The Gender effect is strongly negative in both countries and confirms that, other things being equal, women in physics face more difficulties than men to be promoted. Field effects are also significant, with some relevant differences across ranks. $^{32}$

As for productivity, its effect on the probability of being promoted is captured by the two variables Quality flow and Quantity flow, whose estimated

32 In Italy, promotion to PO appears to be easier in Fisica teorica (Field FIS/02) rather than Fisica della materia (Field FIS/03, the reference dummy). On the other hand the chances of being promoted to a PA position are higher in Fisica sperimentale (Field Fis/01). In France, promotion to PR are more likely in Milieux dilués et optique (Field 30), compared to Milieux denses et matériaux (Field 28). 
coefficients differ across countries. In Italy, promotion seems to be affected largely by quantity, the impact of quality being negligible for promotions to $\mathrm{PO}$ but negative to PA position ${ }^{33}$. In France quality, but not quantity, affects positively and significantly the probability of promotion to $\mathrm{PR}^{34}$.

\subsection{Productivity equation}

Results from the productivity equations for Italy and France are reported in Tables 6 and 7. In Table 6 the dependent variable is quantity while Table 7 refers to quality. As expected, the age of academics has a negative impact on both the quantity and quality of articles published. In all equations, this is captured by the age group coefficients, which are all negative and significant (with the exception of Age group 1) and increasingly larger when moving from Age group 3 to Age group $5^{35}$.

${ }^{33}$ Variables quality and quantity flow are highly correlated

${ }^{34}$ Notice that the variable Zero flow is positive and statistically significant in all the selection equations. At first sight this result looks puzzling, but in fact it depends on the design of the pooled-probit exercise. In such exercise the dependent variable is a binary one, which takes value one from time $t$ onward, for all scientists who are promoted at time $t$. After $t$ many scientists may stop publishing altogether, so the value one of the dummy Zero flow is often coupled with unitary model outcome. This variable should be considered as a control for the zeros and its omission does not affect the estimates of other regressors.

${ }^{35}$ In a separate regression exercise we have tested the effect of age on productivity of Italian PO, in the absence of controls for participation to large and/or international projects. In this case, the impact of age on productivity (quantity) appears to be negligible. One interpretation is that PO 
[TABLE 6 AND TABLE 7 ABOUT HERE]

Elaborations on the estimated coefficients in Table 6 tell us that over-60 Italian POs produce around 2.25 articles per year less than their 30-to-40 year old peers. A similar comparison suggests that over- 60 French PR produce 0.65 articles per year less than their younger peers ${ }^{36}$. As for quality (Table 7), Italian POs seem the most affected by age, with over-60s exhibiting a loss of average impact factor per year equal to 1.99. Since we observe the productivity conditional to the scientist's ranking in 2005, our estimates capture on one side the life cycle effect, as discussed in section 4.3; but on the other side, and only for RUs, PAs and MCFs, they capture the effect of less productive scientists that are not promoted and remain at lower academic ranks.

suffer of a productivity loss at the individual level, which they compensate by participating to large international projects.

${ }^{36}$ Throughout Section 5 we express the impact of the covariates on quantity (the number of articles) or quality, (average impact factor) by means of marginal effects, which we compute on the basis of the estimated coefficients in Tables 6 and 7. The marginal effect of any dummy covariates is given by: $\Delta y=e^{\overline{R-D}} \cdot\left(e^{\beta}-1\right)$ where $e^{\overline{R-D}}$ is the average predicted value of the model minus the dummy $\mathrm{D}$ effect and $\beta$ is the coefficient of $\mathrm{D}$. As for the marginal effects of a continuous or discrete covariate, this is given by: $\frac{d(1+y)}{d(1+x)}=\frac{d \log (1+y)}{d \log (1+x)} \cdot \overline{\left(\frac{1+y}{1+x}\right)}$ where $\overline{\left(\frac{1+y}{1+x}\right)}$ is the average value of the ratio between the dependent variable and the covariate and $\frac{d \log (1+y)}{d \log (1+x)}$ is the coefficient (elasticity) estimated in the regressions. 
Gender impacts differently in Italy and in France, and across academic ranks. With reference to quantity estimates in Table 6, we observe that Italy exhibits a negative gender effect only for RU: Italian ricercatrici publish 0.27 papers less than their male peers, per year; on the contrary, women in PA or PO position are not less productive than their male equivalents. As for France, we observe a negative gender effect on quantity both for $\mathrm{PR}$ and for $\mathrm{MCF}$, where women produce respectively 0.26 and 0.13 papers less than men, per year. Results for quality are similar, the women's gap in average impact factor per year being: -0.49 for PR, 0.24 for $\mathrm{MCF}$, and -0.39 for RU. In the absence of additional data, we can provide intuitive explanations for such results. In particular, we notice that, for Italy, the existence of a gender effect only for the most junior position (RU) is consistent with the possibility that gender matters more at the early career stages, when familiar engagements may also be demanding. Thus, a self-selection process may take place, by which only the best or most motivated researchers try to access the higher ranks, at which the gender effect appears to be less remarkable or even not significant. If this was the correct interpretation, we need then to explain why we observe a gender effect also at the senior level of French PR. In this respect we note that women in France are 10\% of PR (as opposed to 6\% of Italian PO). Moreover, going back to the selection equation (Table 5), we notice that the negative gender effect on promotion is smaller for PR relatively to PO. One possibility is therefore that French women face less difficulties in the promotion to full professorship 
(thanks, for example, to the first centralized step managed by $\mathrm{CNU}$ ), which may explain why we observe the negative gender to persist at the top academic rank.

The estimated coefficient of the Wave 1980 and Wave 1985 dummies is negative and significant in the quantity model, for all positions (with the exception of French PR; see Table 6), while it is still negative, but never significant in the quality model (with the exception of Italian RU where it is significant and PR and PA where is positive; see Table 7). As for quantity, POs promoted to such rank in 1980 publish 0.20 articles less per year than other POs. Similarly, PAs and RUs last promoted in 1980 publish respectively 0.19 and 0.35 articles less per year than colleagues last promoted in more recent years. The effect for France is still noticeable, but less pronounced: MCFs who were recruited in 1985 (and never promoted to PR) produce 0.05 articles less than other MCFs, per year. Bearing in mind that we do not observe how many scientists, among those who entered the academic system as RU or MCF in 1980 and 1985, have been subsequently promoted to higher positions (as opposed to having retired or left Italy), the interpretation of our results may be as follows: the 1980 and 1985 big recruitment waves in the two countries filled up the RU, PA, and MCF positions with less productive scientists, who did not progress much further in their careers, and are now responsible for the negative signs we observe in Table 6 and (for RU) in Table 7. We can estimate the total scientific productivity loss due to the entry wave of 1980 in Italy, where the effect is stronger, comparing the total number of papers published by scientists promoted in these entry cohorts, with the estimated 
number of papers published by scientists from other entry cohorts, other things being equal. This exercise suggests that the 62 Italian POs promoted in 1980 have published about 314 articles less than what expected by similar POs from other cohorts, over the same years of activity. Similar calculations suggest a production gap of 785 articles by PAs and of 639 articles by RUs from the 1980 wave, for a total scientific loss of around 1738 articles. Our calculations may under-estimate the effects of the massive entry waves, since they are based on a sample which includes only academics who published at least one article since 1975. A large share of the French and Italian unproductive scientists, excluded from the regression sample, comes precisely from the 1985 and 1980 waves [respectively $17 \%(40 / 235)$ and $36.5 \%(19 / 52)]$, so that their inclusion would have increased further the size of the estimated coefficients for the two wave dummies ${ }^{37}$.

These figures suggest that the percentage of unproductive scientists over all scientists hired during the 1980 and 1985 waves is at least two (for MCF) or three times higher (for PA and RU) than the same percentage for the rest of the sample ${ }^{38}$.

\footnotetext{
${ }^{37}$ More precisely, among the Italians hired during the 1980 wave the unproductive PO, PA and RU are respectively $1.6 \%, 6.7 \%$ and $7.6 \%$. In France $21.9 \%$ are MCF and $9.8 \%$ are PR. Notice that, following referee request we rerun all the regression including all scientists with zero publications. The effect of the waves is confirmed and become even stronger.

38 Another peculiarity of the waves is that in Italy were hired considerably younger academics if compared to the average age of hiring in other years; this is true also for PR in France but not for MCF with an average age of 41 instead of the usual age of 32 in other years. In general there are no
} 
Some descriptive statistics help understanding why the "wave effect" appears to be stronger in Italy than in France. In Italy, over 10\% (62/588) of PO, $26 \%(166 / 618)$ of PA and 14\% (73/511) of RU active in 2005 were promoted to such positions in 1980. In France, only less than 8\% (55/705) of PR and 10\% (121/1212) of MCF reached their present position in 1985. In other words, the 1980 wave in Italy was bigger and produced more enduring effect than its French equivalent. As for Italian RUs, this effect is also visible for the quality-based measure of productivity.

As explained in the previous section, we control for the individuals' unobservable heterogeneity by means of lagged measures of productivity (Quantity before promotion and Quality before promotion). As expected, all such controls bear a positive and significant sign (the only exception being the negative sign of the impact of past quality-productivity on current quantity-productivity in the case of PO).

Productive co-authors impact positively on individual scientists' productivity. For quantity measures of productivity, estimates in Table 6 suggest that Italian PO and French PR and MCF produce 0.08, 0.06 and 0.18 extra articles per year for every additional article produced by their co-authors over the three preceding years. The marginal effect of co-authors' quality on the scientist's quality output per year is positive for all ranks and countries, and it ranges between 0.37 for Italian RU and 0.53 for PR.

big differences for the gender composition of the academics promoted during the waves except for the rank of RU where, during the wave were promoted $14 \%$ more women ( $36 \%$ instead of $22 \%$ ). 
Involvement in large and/or international projects affects strongly a scientist's yearly productivity. This is especially true for Italian POs, where the dummy Large project produces a marginal effect on quantity of more than 5.5 articles per year. Similar results hold also for PAs and RUs, whose productivity is increased significantly by participation to Large project (4.40 and 3.43 more articles per year; the reference group is given by scientists with no publications in the three years before $t$ ). The effect of Large project for France, albeit high if compared to the effect of other covariates, is weaker than in Italy, the marginal effects for PRs and MCFs being respectively equal to 4.63 and 3.33. Even quality is affected by participation to large international projects, with increases in the average impact factor per year comprised between 3.54 (for MCF) and 9.09 (for PO). Scientists who are not involved in large projects, but had at least one foreign co-author in the three years before $t$, also have larger quantity and quality scores than the reference group (but lower than their peers participating to large projects). Italian POs with dummy Small_project_with_foreign_co-authors equal to one, for example, publish 2.41 more papers per year than the reference group. On the other hand, POs with participation to Small_project_with_only_national_co-authors publish 1.50 papers more than the reference group. Similar results hold for all position in both countries.

Controls for field effects also prove significant. Italian POs belonging to Fisica sperimentale (Field Fis/01) and Fisica teorica, modelli e metodi matematici (Field Fis/02) publish respectively 0.46 and 0.65 articles less than colleagues from Fisica 
della materia (Field Fis/03), per year. The quality of the publications is also lower. In France, MCFs belonging to Milieux dilués et optique (Field 30) publish more and higher quality articles if compared to Milieux denses et matériaux (Field 28).

Tables 6 and 7 show also the estimated inverse Mill's ratio (lambda) produced by the Heckman procedure to correct for the problem of selection bias. Its negative sign means that the probability of not being promoted affects negatively the individual scientific productivity. The coefficient is significant for $\mathrm{PR}, \mathrm{PO}$ and $\mathrm{PA}$ in the quantity regressions and for $\mathrm{PR}$ and $\mathrm{PO}$ in the quality regressions. Lack of significance for PA in the quality regression means that the two equations, selection and productivity, could have been estimated separately, without any kind of correction for endogeneity of the academic rank.

\section{Conclusions}

In this paper we have investigated the determinants of scientific productivity for a sample comprising most of the academic physicists active in French and Italian universities in 2004-2005. We have performed this analysis both conditional on being in an assistant or professorial position (MCF and PR in France and RU, PA and PO in Italy) and together with a joint analysis of the determinants of promotion to professor (from MCF to PR in France and RU to PA and PA to PO in Italy). We consider this approach to be more informative than 
most alternatives, as well as better at addressing the interrelated econometric problems of endogeneity, selectivity, and unobserved heterogeneity.

Our estimates of promotion equations show that the probability of a French or Italian physicist to be promoted professor increases with age until he/she reaches his/her sixties. Other things being equal, we also find that such probability is significantly lower for women. In Italy promotion is influenced by the quantity of past publications (quantity-productivity lagged flow), and in France, it is influenced by their quality (quality-productivity lagged flow). In both academic systems we observe big recruitments waves, in 1980 and 1985, which affect significantly the probability of promotion.

In the productivity equations we show that the age of academics has a negative impact on the quantity and quality of articles published by French PR and Italian PO publications. For the other academic ranks the age effect is mixed with the other effect of not being promoted, due to the database design. French MCFs and Italian PAs and RUs are characterized by a strong negative impact of age.

As for gender effect on productivity, Italian women at the early stage of their careers (for example RU) are penalized in their publication activity. However, if Italian women manage to be promoted to higher ranks, then they publish as much as their male colleagues. On the contrary, in France we observe a negative gender effects across all ranks. We find evidence that the work environment is very important for individual scientists' productivity. In particular being involved 
in large projects, or at least having an international collaboration, has a strong and positive effect on quantity and quality of published articles

Finally we show that the big recruitment and promotion waves of 1980 and 1985 had negative and lasting effects on the average scientific productivity of the two countries, especially for Italy. Such big waves came after a prolonged spell with no recruitment of new scientists and few promotions, and were the result of policy provisions aimed at providing permanent positions for many scientists with temporary assignments. Many of the physicists recruited in these years appear not to have progressed much in their careers, and to have been persistently less productive than the average physicists of the same rank, recruited or promoted in other years. Our results on age, gender and past productivity confirm many of the ones already found in the literature, but our findings on the enduring negative effects of en masse recruitment in France and, most notably, in Italy are more original. 


\section{References}

Allison, P.D. and Long, J.S. (1990), 'Departmental effects on scientific productivity', American Sociological Review, 55(4), 469-478.

Ben-David, J. (1992), Centers of Learning: Britain, France, Germany, United States. Transaction Publishers.

Breschi S., Lissoni F., Montobbio F. (2007). 'The Scientific Productivity Of Academic Inventors: New Evidence From Italian Data', Economics of Innovation and New Technology 16(2), 101-118

Breschi S., Lissoni F., Montobbio F. (2008) 'University patenting and scientific productivity. A Quantitative Study of Italian Academic Inventors', European Management Review 5(2), 91-109

Bonaccorsi, A. and Daraio, C. (2003), 'Age effects in scientific productivity', Scientometrics, 58(1), 49-90.

Cattell, J.M. (1903), 'Statistics of American Psychologists', American Journal of Psychology, $14,310-328$.

Chevaillier, T. (2001), 'French academics: Between the professions and the civil service', Higher Education, 41(1), 49-75.

Clark, B.R. (1977), Academic Power in Italy: Bureaucracy and Oligarchy in a National University System. University of Chicago Press.

Clark, B.R. (1993), The Research Foundations of Graduate Education: Germany, Britain, France, United States, Japan. University of California Press 
Crane, D. (1972), Invisible Colleges: Diffusion of Knowledge in Scientific Communities. University of Chicago Press.

David, P.A. (1994), ‘Positive Feedbacks and Research Productivity in Science: Reopening Another Black Box', The Economics of Technology, Elsevier, 65-89.

Dubin, J.A. and Rivers, D. (1989), ‘Selection Bias in Linear Regression, Logit and Probit Models', Sociological Methods and Research, 18(2), 360-90.

Ehrenberg, R.G., Kasper, H. and Rees, D.I. (1990), ‘Faculty Turnover at American Colleges and Universities: Analysis of AAUP Data', Working Paper No. 3239. Available at SSRN

Etzkowitz, H., Kemelgor, C. and Uzzi, B. (2000), Athena Unbound: The Advancement of Women in Science and Technology. Cambridge University Press.

Fox, M.F. (1999), 'Gender, Hierarchy, and Science', Handbook of the Sociology of Gender, 441457.

Godin, B. (2006), 'On the origins of bibliometrics', Scientometrics, 68(1), 109-133.

Godin, B. (2007), ' From Eugenics to Scientometrics: Galton, Cattell, and Men of Science', Social Studies of Science, 37(5), 691.

Graham, H.D. and Diamond, N. (1997), The Rise of American Research Universities: Elites and Challengers in the Postwar Era. Johns Hopkins University Press.

Hall, B.H., Mairesse, J. and Turner, L. (2007), 'Identifying Age, Cohort and Period Effects in Scientific Research Productivity: Discussion and Illustration Using Simulated and Actual Data on French Physicists', Economics of Innovation and New Technology, 16(1/2), 159177. 
Heckman, J. (1979),' Sample Selection Bias as a Specification Error', Econometrica, 47(1), $153-161$.

King, DA. (2004); ‘The Scientific Impact of Nations', Nature, 430, 311-316

Lee, S. and Bozeman, B. (2005), 'The Impact of Research Collaboration on Scientific Productivity', Social Studies of Science, 35(5), 673.

Levin, S.G. and Stephan, P.E. (1991), 'Research Productivity Over the Life Cycle: Evidence for Academic Scientists', American Economic Review, 81(1), 114-132.

Levin, S.G. and Stephan, P.E. (1998), 'Gender Differences in the Rewards to Publishing in Academe: Science in the 1970s', Sex Roles, 38(11), 1049-1064.

Long, J.S. (1978), ‘Productivity and Academic Position in the Scientific Career, 'American Sociological Review, 43(6), 889-908.

Long, J.S. (1993), 'Rank Advancement in Academic Careers: Sex Differences and the Effects of Productivity', American Sociological Review, 58(5), 703-722.

Long, J.S. and Fox, M.F. (1995), 'Scientific Careers: Universalism and Particularism', Annual Reviews in Sociology, 21(1), 45-71.

Lotka, A.J. (1926), 'The Frequency Distribution of Scientific Productivity', Journal of the Washington Academy of Sciences, 16(12), 317-323.

Mairesse, J. and Turner, L. (2006), 'Measurement and Explanation of the Intensity of Copublication in Scientific Research: An Analysis at the Laboratory Level', in New Frontiers in the Economics of Innovation and New Technology: Essays in honour of Paul David, eds. C. Antonelli, D. Foray, B. Hall and E. Steinmueller, Edward Elgar Publishing, 255-295.

May, RMM. (1997), 'The Scientific Wealth of Nations', Science, 275, 793-796. 
Merton, R.K. (1968), 'The Matthew Effect in Science', Science, 159(3810), 56-63.

Merton, R.K. (1988), ‘The Matthew Effect in Science, II: Cumulative Advantage and the Symbolism of Intellectual Property' Isis, 79(4), 606.

Moscati, R. (2001), 'Italian University Professors in Transition', Higher Education, 41(1), $103-129$.

Musselin, C. (2005), Le Marché des Universitaires: France, Allemagne, États-Unis. Presses de Sciences Po.

Pezzoni, M., Sterzi, V. and Lissoni, F. (2009), 'Career Progress in Centralized Academic Systems: an Analysis of French and Italian Physicists', KITeS Working Paper 27, Università “L.Bocconi”, Milano

Price, D.J. and Beaver, D.D. (1966), 'Collaboration in an Invisible College' , American Psychologist, 1966, 1011-8.

Spelke, E.S. (2005), 'Sex Differences in Intrinsic Aptitude for Mathematics and Science?: A Critical Review', American Psychologist, 60(9), 950.

Turner, L. and Mairesse, J. (2002), 'Individual Productivity Differences in Scientific Research: An Econometric Exploration of French Physicists' Publications', Cahiers de la Maison des Sciences Economiques n66, Université Paris I- Panthéon-Sorbonne. Revised 2006.

Wooldridge J. (2002), Econometric Analysis of Cross Section and Panel Data. The MIT Press, Cambridge, Mass. 
Figures 
Figure 1: Rank distribution of physicists active in 2004-05 in France (MCF, PR) and in Italy (RU, PA, PO)

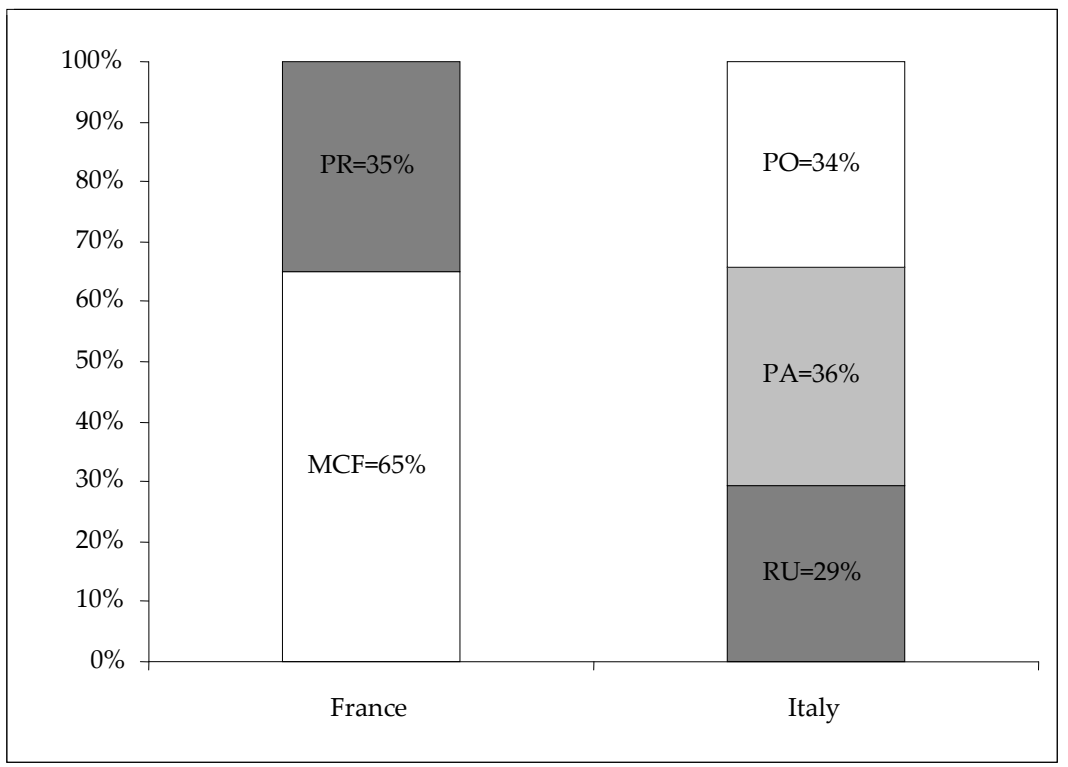

Source: Authors elaboration on ministerial records

Figure 2: Distribution of physicists active in 2004-05 in France by year of recruitment (MCF) or year of last promotion (PR)

\section{France}

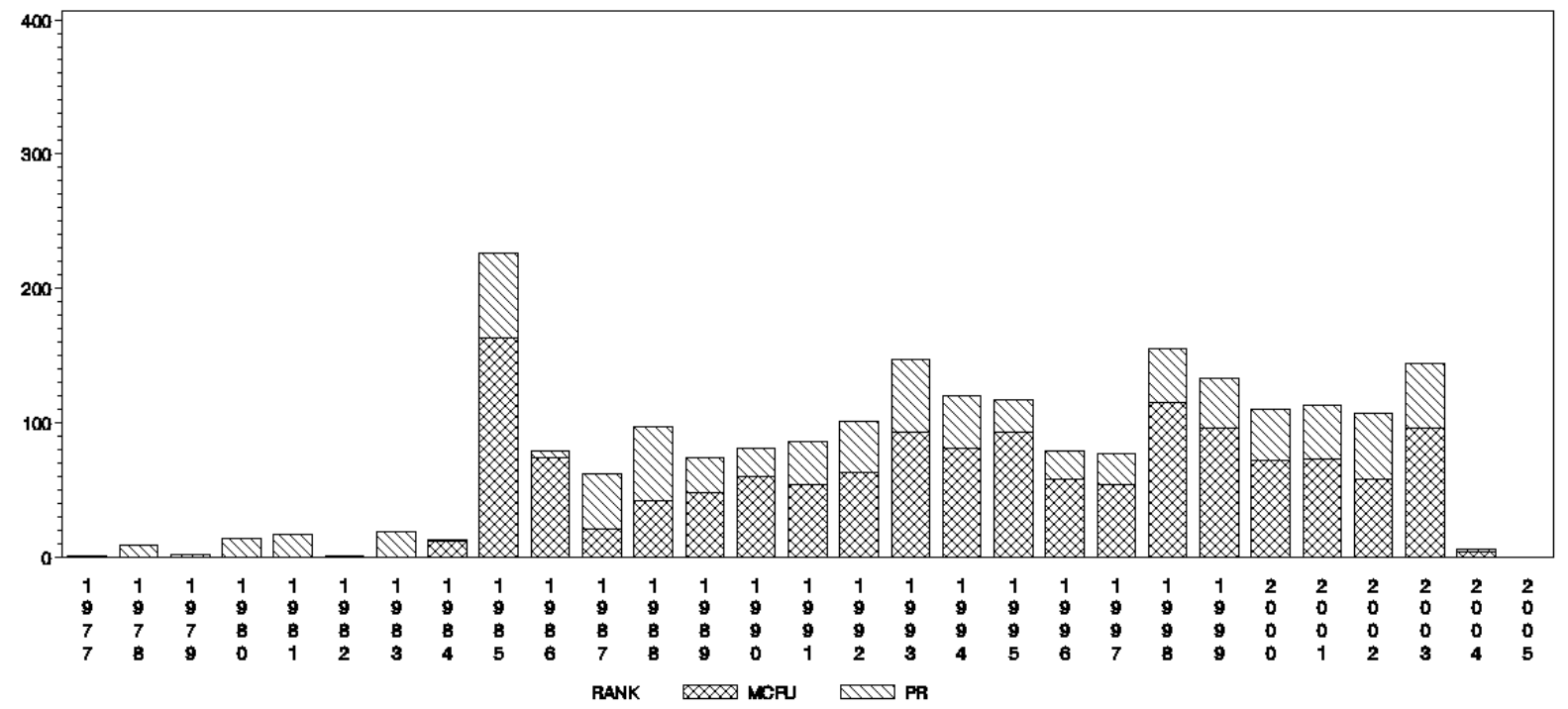

Source: Authors elaboration on ministerial records 
Figure 3: Distribution of physicists active in 2004-05 in Italy by year of recruitment (RU) or year of last promotion (PA; PO)

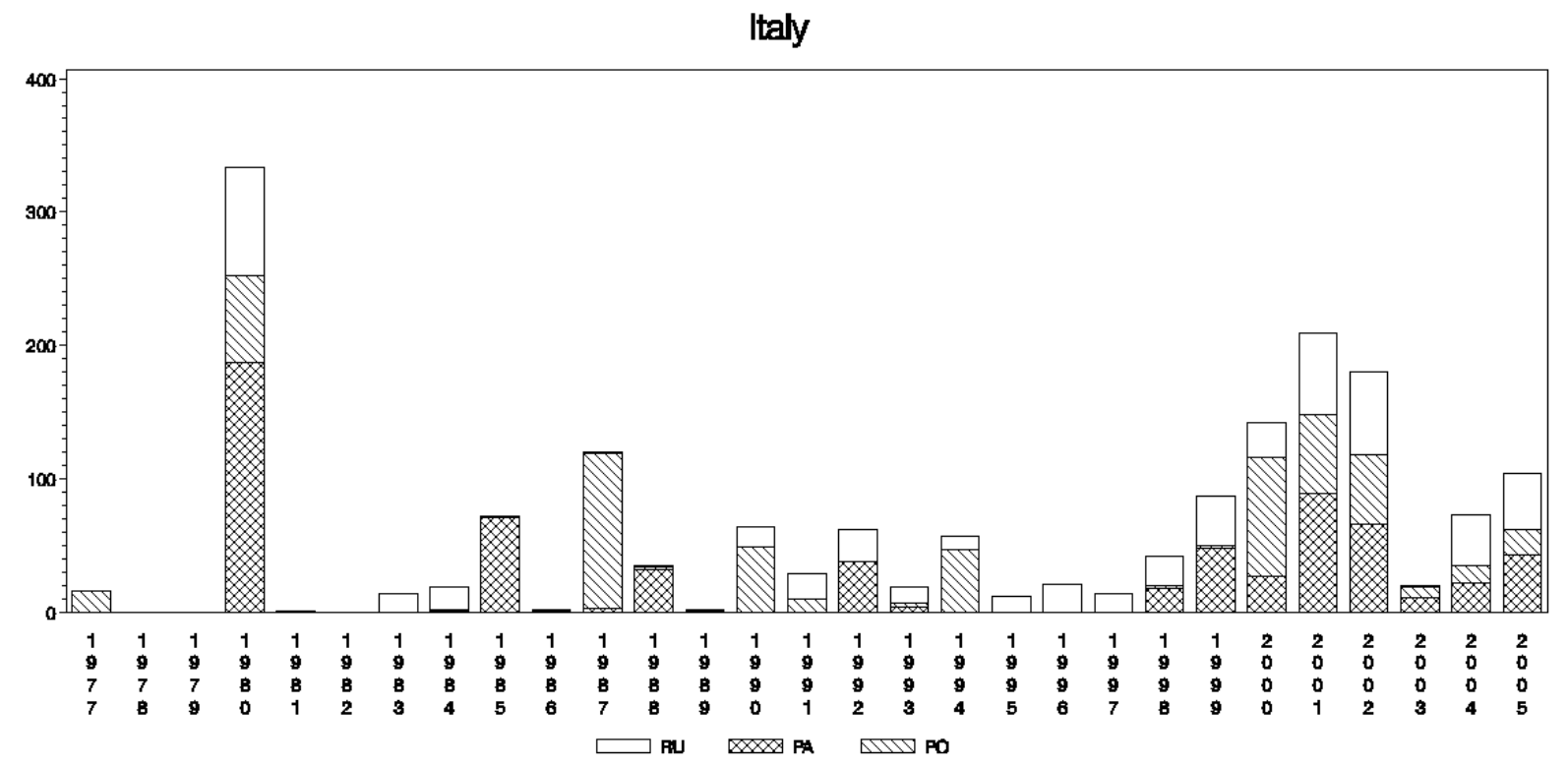

Source: Authors elaboration on ministerial records 
Tables 
Table 1: Disciplinary fields and ranks

\begin{tabular}{|c|c|c|}
\hline & French Universities & Italian Universities \\
\hline Fields & $\begin{array}{l}\text { - } 28 \text { Milieux denses et } \\
\text { matériaux } \\
\text { - } 30 \text { Milieux dilués et optique }\end{array}$ & $\begin{array}{ll}\text { - } & \text { Fis/01 Fisica Sperimentale } \\
\text { - } & \text { Fis/02 Fisica Teorica, Modelli E Metodi Matematici } \\
\text { - } & \text { Fis/03 Fisica Della Materia }\end{array}$ \\
\hline Ranks & $\begin{array}{ll}\text { - } & \text { (PR) Professor } \\
\text { - } & \text { (MCF) Maitre de Conference }\end{array}$ & $\begin{array}{ll}\text { - } & \text { (RU) Ricercatore Universitario } \\
\text { - } & \text { (PA) Professore Associato } \\
\text { - } & \text { (PO) Professore Ordinario }\end{array}$ \\
\hline
\end{tabular}

Table 2: Number of physicists active in 2004-05 in France and Italy by cohort of birth and rank

\begin{tabular}{lrrrrrr}
\hline & \multicolumn{7}{c}{ COHORT } \\
& 1930s & 1940s & 1950s & 1960s & 1970s & Total \\
\cline { 2 - 7 } France-Ranks: & & & & & & \\
PR & 23 & 423 & 179 & 153 & 3 & 781 \\
\% by cohort & 2.94 & 54.16 & 22.92 & 19.59 & 0.38 & 100 \\
MCF & 12 & 341 & 134 & 586 & 357 & 1430 \\
\% by cohort & 0.84 & 23.85 & 9.37 & 40.98 & 24.97 & 100 \\
& & & & & & 2211 \\
Italy-Ranks: & & & & & & \\
PO & 168 & 301 & 137 & 16 & & 622 \\
\% by cohort & 27.01 & 48.39 & 22.03 & 2.57 & & 100 \\
PA & 72 & 222 & 177 & 187 & 3 & 661 \\
\% by cohort & 10.89 & 33.59 & 26.78 & 28.29 & 0.45 & 100 \\
RU & 1 & 54 & 115 & 301 & 62 & 533 \\
\% by cohort & 0.19 & 10.13 & 21.58 & 56.47 & 11.63 & 100 \\
& & & & & & 1816 \\
Total & 276 & 1341 & 742 & 1243 & 425 & 4027 \\
\hline
\end{tabular}

Note: Computed on French and Italian overall samples (before cleaning) -- see Section 4. 
Table 3: Number of physicists in France and Italy, active in 2004-05 by gender and rank in overall sample (before cleaning) and on study sample

\section{Overall sample}

\begin{tabular}{|c|c|c|c|c|c|c|c|}
\hline & \multicolumn{3}{|c|}{ FRANCE } & & \multicolumn{3}{|c|}{ ITALY } \\
\hline & Women & Man & Total & & Women & Men & Total \\
\hline MCF & 410 & 1020 & 1430 & RU & 132 & 401 & 533 \\
\hline PR & 80 & 701 & 781 & PA & 102 & 559 & 661 \\
\hline & & & & $\mathrm{PO}$ & 40 & 582 & 622 \\
\hline Total & 490 & 1721 & 2211 & Total & 274 & 1542 & 1816 \\
\hline
\end{tabular}

Note: Computed on overall French and Italian samples (i.e. before cleaning).

\section{Study sample}

\begin{tabular}{lrrr} 
& \multicolumn{3}{c}{ FRANCE } \\
MCF & Women & Men & Total \\
\cline { 2 - 4 } PR & 299 & 912 & 1211 \\
& 50 & 655 & 705 \\
\hline Total & 349 & 1567 & 1916
\end{tabular}

\begin{tabular}{lrrr} 
& \multicolumn{2}{c}{ ITALY } & \\
& Women & Men & Total \\
\cline { 2 - 4 } RU & 124 & 387 & 511 \\
PA & 93 & 525 & 618 \\
PO & 38 & 550 & 588 \\
\hline Total & 255 & 1462 & 1717
\end{tabular}

Note: Computed on French and Italian study samples (i.e. after cleaning for homonymy and "zero-productive' academics). 
Table 4: Dependent and explanatory variables in promotion and productivity equations

VARIABLE

DEFINITION

\begin{tabular}{|c|c|}
\hline Promotion & $\begin{array}{l}\text { Step indicator for being promoted in year } t(p):=0 \text { if promoted [i.e., } t>=t(p) \text { ], and }=1 \text { if } \\
\text { not promoted [i.e., } t<t(p) \text { ]. }\end{array}$ \\
\hline Quantity-productivity & Logarithm of the numbers of articles published in year $t$, plus 1 \\
\hline Quality-productivity & $\begin{array}{l}\text { Logarithm of the average five years impact factor in year } t \text { for the journals in which } \\
\text { articles have been published in that year, plus } 1\end{array}$ \\
\hline \multicolumn{2}{|c|}{ Explanatory variables in the promotion equations only: } \\
\hline $\begin{array}{l}\text { Quantity-productivity } \\
\text { lagged flow }\end{array}$ & Logarithm of the average number of articles in the three years $t-2, t-3$ and $t-4$, plus 1 \\
\hline $\begin{array}{l}\text { Quality-productivity } \\
\text { lagged flow }\end{array}$ & $\begin{array}{l}\text { Logarithm of the average five years impact factor of the journals in which articles have } \\
\text { been published in the three years } t-2, t-3 \text { and } t-4 \text {, plus } 1 \text {. }\end{array}$ \\
\hline Zero lagged flow & Dummy=1 when Quantity flow=Quality flow $=0$ (and $=0$ if not). \\
\hline Academics per year & Estimates of the number of academics promoted in year $t$ as PR, PA or PO. \\
\hline \multicolumn{2}{|c|}{ Explanatory variables in the productivity equations only: } \\
\hline $\begin{array}{l}\text { Quantity-productivity } \\
\text { before promotion }\end{array}$ & $\begin{array}{l}\text { Logarithm of the average number of articles per year published before the year of } \\
\text { recruitment or last promotion, plus } 1\end{array}$ \\
\hline $\begin{array}{l}\text { Quality-productivity } \\
\text { before promotion }\end{array}$ & $\begin{array}{l}\text { Logarithm of the average impact factor of the journals in which articles have been } \\
\text { published before the year of recruitment or last promotion, plus } 1 \text {. }\end{array}$ \\
\hline Co-authors quantity & $\begin{array}{l}\text { Logarithm of the moving average of co-authors' number of articles (with other } \\
\text { scientists than the author) in the three years } t-1, t-2 \text { and } t-3 \text {, plus } 1 \text {. }\end{array}$ \\
\hline Co-authors quality & $\begin{array}{l}\text { Logarithm of } 1 \text { plus the moving average of average impact factor of the articles } \\
\text { published by the co-authors (with other scientists than the author) in the three years } t \text { - } \\
1, t-2 \text { and } t-3 \text {, plus } 1 \text {. }\end{array}$ \\
\hline $\begin{array}{l}\text { Co-authors quantity and } \\
\text { quality zeros }\end{array}$ & $\begin{array}{l}\text { Dummy }=1 \text { when co-authors quantity is } 0 \text { (and=0 if not); and Dummy=1 when co-authors } \\
\text { quality is } 0 \text { (and =0 if not). }\end{array}$ \\
\hline $\begin{array}{l}\text { Co-authors number and } \\
\text { affiliation dummies }\end{array}$ & $\begin{array}{l}\text { Large Project Dummy }=1 \text { if in the three years before } t(t-1, t-2 \text { and } t-3) \text { scientists have at } \\
\text { least one article with } 30 \text { or more co-authors (and }=0 \text { if not); } \\
\text { Small Project with Foreign co-authors Dummy }=1 \text { if in the three years before } t(t-1, t-2 \text { and } t \text { - } \\
\text { 3) scientists have no articles with } 30 \text { or more co-authors and have at least one article } \\
\text { with an address indicating at least one foreign co-authors ( } \text { and }=0 \text { if not); } \\
\text { Small Project with only national co-authors Dummy }=1 \text { if in the three years before } t(t-1, t-2 \\
\text { and } t-3 \text { ) scientists have no articles with } 30 \text { or more co-authors and have no articles with } \\
\text { addresses indicating foreign co-authors (and }=0 \text { if not); } \\
\text { Small Project with co-authors of unknown affiliations Dummy }=1 \text { if in the three years before } \\
t(t-1, t-2 \text { and } t-3 \text { ) scientists have no articles with } 30 \text { or more co-authors and have only } \\
\text { articles with missing addresses (and }=0 \text { if not). }\end{array}$ \\
\hline $\begin{array}{l}\text { Zero in three preceding } \\
\text { years }\end{array}$ & $\begin{array}{l}\text { Dummy }=1 \text { when scientists published } 0 \text { articles in the three years } t-1, t-2 \text { and } t-3 \text { before } \\
\text { year of observation (and }=0 \text { if not). }\end{array}$ \\
\hline Zeros before promotion & Dummy $=1$ when Quantity before promotion $=$ Quality before promotion $=0$ (and $=0$ if not). \\
\hline Zeros after promotion & $\begin{array}{l}\text { Dummy }=1 \text { when scientists published } 0 \text { articles after recruitment or last promotion } \\
\text { (and }=0 \text { if not). }\end{array}$ \\
\hline
\end{tabular}




\section{Table 4 (continued): Dependent and explanatory variables in promotion and productivity} equations

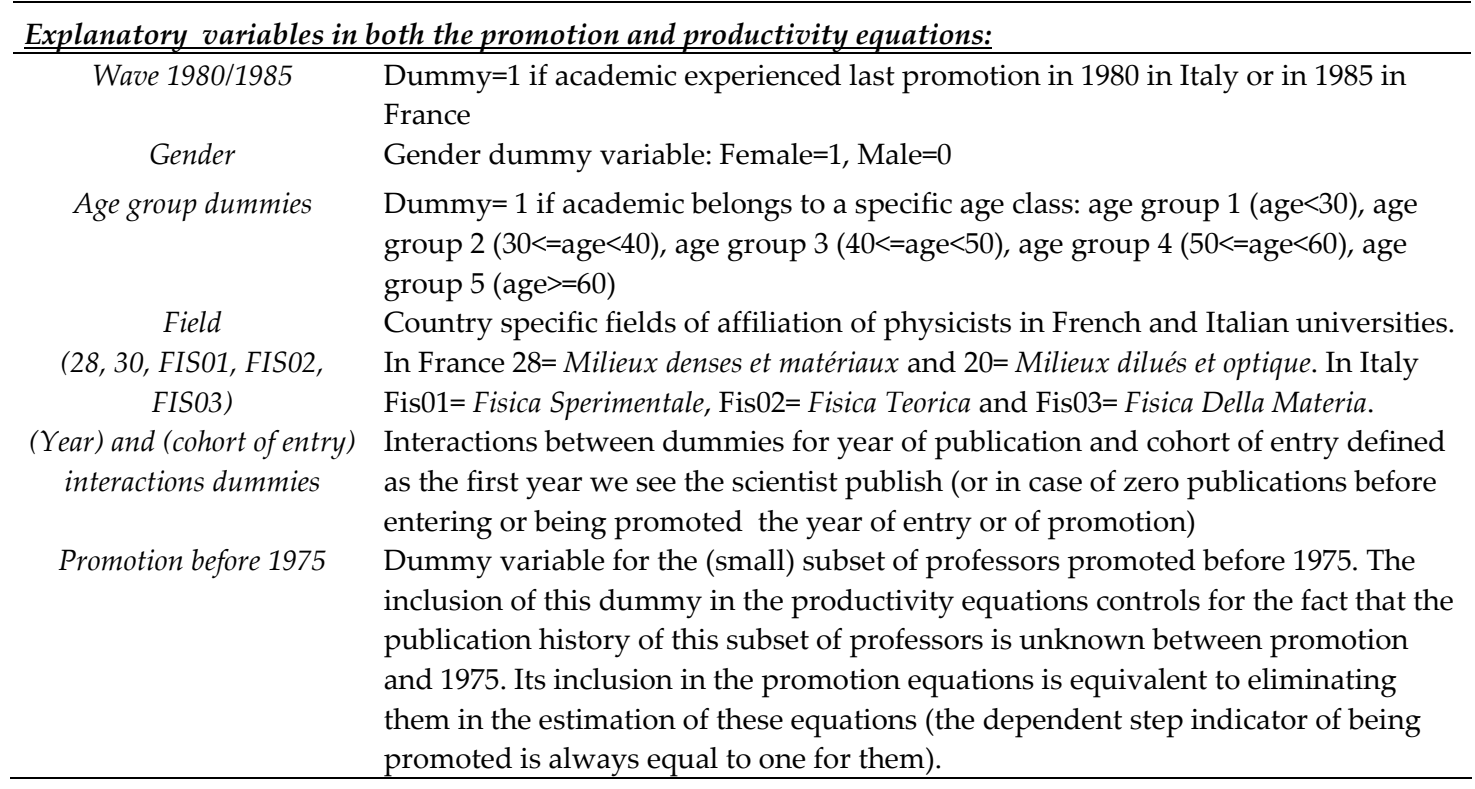


Table 5: Probit equations for professor promotion

\begin{tabular}{|c|c|c|c|}
\hline & PR (FR) & $\mathrm{PO}(\mathrm{IT})$ & PA (IT) \\
\hline \multirow[t]{2}{*}{ Quantity flow } & 0.018 & $0.048^{* * *}$ & $0.059^{* * *}$ \\
\hline & $(0.011)$ & $(0.012)$ & $(0.0074)$ \\
\hline \multirow[t]{2}{*}{ Quality flow } & $0.060^{* * *}$ & -0.0050 & $-0.025^{* * *}$ \\
\hline & $(0.011)$ & $(0.014)$ & $(0.0088)$ \\
\hline \multirow[t]{2}{*}{ Zero flow } & $0.15^{* * *}$ & $0.18^{* * *}$ & $0.12^{* * *}$ \\
\hline & $(0.013)$ & $(0.022)$ & $(0.0079)$ \\
\hline \multirow[t]{2}{*}{ Academics per year } & $0.0046^{* *}$ & $0.0023^{* * *}$ & $0.012^{* * *}$ \\
\hline & $(0.0018)$ & $(0.00090)$ & $(0.00061)$ \\
\hline \multirow[t]{2}{*}{ Wave 1985 (FR)/ Wave 1980 (IT) } & $0.18^{* * *}$ & $0.40^{* * *}$ & $0.38^{* * *}$ \\
\hline & $(0.0095)$ & $(0.0084)$ & $(0.0097)$ \\
\hline \multirow[t]{2}{*}{ Gender } & $-0.11^{* * *}$ & $-0.15^{* * *}$ & $-0.068^{* * *}$ \\
\hline & $(0.021)$ & $(0.024)$ & $(0.012)$ \\
\hline Age group 1 & n.r. & n.r. & n.r. \\
\hline \multirow[t]{2}{*}{ Age group 3} & $0.27^{* * *}$ & $0.50^{* * *}$ & $0.15^{* * *}$ \\
\hline & $(0.012)$ & $(0.018)$ & $(0.0093)$ \\
\hline \multirow[t]{2}{*}{ Age group 4} & $0.37^{* * *}$ & $0.68^{* * *}$ & $0.22^{* * *}$ \\
\hline & $(0.013)$ & $(0.014)$ & $(0.0097)$ \\
\hline \multirow[t]{2}{*}{ Age group 5} & $0.23^{* * *}$ & $0.56^{* * *}$ & n.r. \\
\hline & $(0.010)$ & $(0.011)$ & \\
\hline \multirow[t]{2}{*}{ Field 30 (FR)/Fis01 (IT) } & $0.022^{* *}$ & 0.0020 & $0.029^{* * *}$ \\
\hline & $(0.0092)$ & $(0.013)$ & $(0.0088)$ \\
\hline \multirow[t]{2}{*}{ Field Fis02 (IT) } & & $0.13^{* * *}$ & 0.0090 \\
\hline & & $(0.014)$ & $(0.011)$ \\
\hline Constant & - & - & - \\
\hline Observations & 14094 & 14114 & 12165 \\
\hline Number of physicists & 705 & 588 & 618 \\
\hline
\end{tabular}

See Table 4 for the precise definitions of the variables. The coefficients given in the Table are the marginal effects. Their standard errors are given in parentheses, and the corresponding P-values if less than 0.01, 0.05 and 0.10 are respectively denoted by ***** and *.The equation include controls for the (year) and (cohort of entry) interactions and for the promotion before 1975 dummy variable; their coefficients are not reported in the Table. 
Table 6. Quantity-productivity equation.

\begin{tabular}{|c|c|c|c|c|c|}
\hline VARIABLES & $\begin{array}{c}\text { PR(FR) } \\
\text { Heckman }\end{array}$ & $\begin{array}{c}\mathrm{MCF}(\mathrm{FR}) \\
\mathrm{OLS}\end{array}$ & $\begin{array}{c}\text { PO(IT) } \\
\text { Heckman }\end{array}$ & $\begin{array}{c}\text { PA(IT) } \\
\text { Heckman }\end{array}$ & $\begin{array}{c}\text { RU(IT) } \\
\text { OLS }\end{array}$ \\
\hline Quantity before promotion & $\begin{array}{l}0.45^{* * *} \\
(0.019)\end{array}$ & $\begin{array}{l}0.33^{* * *} \\
(0.017)\end{array}$ & $\begin{array}{l}0.57^{* * *} \\
(0.022)\end{array}$ & $\begin{array}{l}0.37^{* * *} \\
(0.020)\end{array}$ & $\begin{array}{l}0.48^{* * *} \\
(0.023)\end{array}$ \\
\hline Quality before promotion & $\begin{array}{c}0.080^{* * *} \\
(0.020)\end{array}$ & $\begin{array}{c}0.058^{* * *} \\
(0.012)\end{array}$ & $\begin{array}{c}-0.094^{* * *} \\
(0.022)\end{array}$ & $\begin{array}{c}0.00038 \\
(0.019)\end{array}$ & $\begin{array}{c}0.013 \\
(0.023)\end{array}$ \\
\hline Co-authors quantity & $\begin{array}{l}0.036^{*} \\
(0.019)\end{array}$ & $\begin{array}{l}0.13^{* * *} \\
(0.015)\end{array}$ & $\begin{array}{l}0.047^{* *} \\
(0.020)\end{array}$ & $\begin{array}{l}0.0095 \\
(0.021)\end{array}$ & $\begin{array}{l}-0.041 \\
(0.025)\end{array}$ \\
\hline Co-authors quality & $\begin{array}{c}0.069^{* * *} \\
(0.026)\end{array}$ & $\begin{array}{c}0.028 \\
(0.021)\end{array}$ & $\begin{array}{c}0.018 \\
(0.028)\end{array}$ & $\begin{array}{c}0.036 \\
(0.028)\end{array}$ & $\begin{array}{l}-0.021 \\
(0.036)\end{array}$ \\
\hline Co-authors zero Dummy & $\begin{array}{l}-0.017 \\
(0.053)\end{array}$ & $\begin{array}{l}0.099^{* *} \\
(0.044)\end{array}$ & $\begin{array}{l}-0.13^{* *} \\
(0.060)\end{array}$ & $\begin{array}{l}-0.083 \\
(0.058)\end{array}$ & $\begin{array}{c}-0.27^{* * *} \\
(0.077)\end{array}$ \\
\hline Large Project Dummy & $\begin{array}{l}1.09^{* * *} \\
(0.049)\end{array}$ & $\begin{array}{l}1.14^{* * *} \\
(0.038)\end{array}$ & $\begin{array}{l}1.13^{* * *} \\
(0.039)\end{array}$ & $\begin{array}{l}1.18^{* * *} \\
(0.032)\end{array}$ & $\begin{array}{l}0.96^{* * *} \\
(0.045)\end{array}$ \\
\hline Small Project with Foreign co-authors Dummy & $\begin{array}{l}0.55^{* * *} \\
(0.023)\end{array}$ & $\begin{array}{l}0.43^{* * *} \\
(0.015)\end{array}$ & $\begin{array}{l}0.68^{* * *} \\
(0.035)\end{array}$ & $\begin{array}{l}0.55^{* * *} \\
(0.025)\end{array}$ & $\begin{array}{l}0.39^{* * *} \\
(0.037)\end{array}$ \\
\hline Small project with only National co-authors Dummy & $\begin{array}{l}0.33^{* * *} \\
(0.024)\end{array}$ & $\begin{array}{l}0.21^{* * *} \\
(0.016)\end{array}$ & $\begin{array}{l}0.39^{* * *} \\
(0.035)\end{array}$ & $\begin{array}{l}0.34^{* * *} \\
(0.024)\end{array}$ & $\begin{array}{l}0.18^{* * *} \\
(0.035)\end{array}$ \\
\hline $\begin{array}{l}\text { Small Project with co-authors of unknown affiliations } \\
\text { Dummy }\end{array}$ & $\begin{array}{l}0.22^{* * *} \\
(0.035)\end{array}$ & $\begin{array}{l}0.14^{* * *} \\
(0.024)\end{array}$ & $\begin{array}{l}0.22^{* * *} \\
(0.075)\end{array}$ & $\begin{array}{l}0.24^{* * *} \\
(0.050)\end{array}$ & $\begin{array}{l}0.082 \\
(0.072)\end{array}$ \\
\hline Wave 1985 (FR)/ Wave 1980 (IT) & $\begin{array}{c}0.028 \\
(0.024)\end{array}$ & $\begin{array}{l}-0.032^{* *} \\
(0.016)\end{array}$ & $\begin{array}{l}-0.061^{* *} \\
(0.027)\end{array}$ & $\begin{array}{c}-0.080^{* * *} \\
(0.025)\end{array}$ & $\begin{array}{l}-0.14^{* * *} \\
(0.047)\end{array}$ \\
\hline Gender & $\begin{array}{l}-0.11^{* * *} \\
(0.029)\end{array}$ & $\begin{array}{c}-0.079^{* * *} \\
(0.012)\end{array}$ & $\begin{array}{c}0.047 \\
(0.038)\end{array}$ & $\begin{array}{l}-0.024 \\
(0.021)\end{array}$ & $\begin{array}{l}-0.11^{* * *} \\
(0.021)\end{array}$ \\
\hline Age group 1 & & $\begin{array}{l}0.097^{* *} \\
(0.043)\end{array}$ & & & $\begin{array}{l}-0.015 \\
(0.16)\end{array}$ \\
\hline Age group 3 & $\begin{array}{l}-0.19^{* * *} \\
(0.047)\end{array}$ & $\begin{array}{c}-0.060^{* * *} \\
(0.020)\end{array}$ & $\begin{array}{l}-0.42^{* * *} \\
(0.095)\end{array}$ & $\begin{array}{l}-0.11^{* * *} \\
(0.034)\end{array}$ & $\begin{array}{l}-0.078^{* *} \\
(0.032)\end{array}$ \\
\hline Age group 4 & $\begin{array}{l}-0.26^{* * *} \\
(0.061)\end{array}$ & $\begin{array}{l}-0.11^{* * *} \\
(0.027)\end{array}$ & $\begin{array}{c}-0.64^{* * *} \\
(0.11)\end{array}$ & $\begin{array}{l}-0.27^{* * *} \\
(0.043)\end{array}$ & $\begin{array}{l}-0.25^{* * *} \\
(0.057)\end{array}$ \\
\hline Age group 5 & $\begin{array}{l}-0.31^{* * *} \\
(0.066)\end{array}$ & $\begin{array}{l}-0.074^{*} \\
(0.040)\end{array}$ & $\begin{array}{c}-0.77^{* * *} \\
(0.12)\end{array}$ & $\begin{array}{l}-0.38^{* * *} \\
(0.048)\end{array}$ & $\begin{array}{c}-0.40^{* * *} \\
(0.12)\end{array}$ \\
\hline Field 30 (FR)/Fis01 (IT) & $\begin{array}{l}0.0011 \\
(0.015)\end{array}$ & $\begin{array}{c}0.054^{* * *} \\
(0.010)\end{array}$ & $\begin{array}{l}-0.13^{* * *} \\
(0.021)\end{array}$ & $\begin{array}{c}0.011 \\
(0.021)\end{array}$ & $\begin{array}{l}-0.013 \\
(0.024)\end{array}$ \\
\hline Field Fis02 (IT) & & & $\begin{array}{l}-0.20^{* * *} \\
(0.023)\end{array}$ & $\begin{array}{l}-0.039 \\
(0.024)\end{array}$ & $\begin{array}{l}-0.055^{* *} \\
(0.027)\end{array}$ \\
\hline Constant & $\begin{array}{c}0.19 \\
(0.18)\end{array}$ & $\begin{array}{c}0.37 \\
(0.53)\end{array}$ & $\begin{array}{l}0.46^{* * *} \\
(0.16)\end{array}$ & $\begin{array}{l}0.056 \\
(0.10)\end{array}$ & $\begin{array}{c}0.26 \\
(0.25)\end{array}$ \\
\hline rho & -0.33 & & -0.30 & -0.27 & \\
\hline $\begin{array}{l}\text { lambda } \\
\text { standard error lambda }\end{array}$ & $\begin{array}{c}-0.20^{* * *} \\
(0.06)\end{array}$ & & $\begin{array}{l}-0.21^{* * *} \\
(0.047)\end{array}$ & $\begin{array}{l}-0.17^{* * *} \\
(0.041)\end{array}$ & \\
\hline Observations & 14094 & 12057 & 14114 & 12165 & 5106 \\
\hline Uncensored observation & 9018 & & 8332 & 8089 & \\
\hline Censored observations & 5076 & & 5782 & 4076 & \\
\hline Number of physicists & 705 & 1211 & 588 & 618 & 511 \\
\hline Sigma & 0.61 & & 0.69 & 0.62 & \\
\hline R-squared & & 0.344 & & & 0.526 \\
\hline
\end{tabular}

See Table 4 for the precise definitions of the variables. We control for the (year) and (cohort of entry) interactions dummies, for the Zero after promotion dummy variable and for the promotion before 1975 dummy variable, all three not reported in the Table. The Zero in preceding years is normalized to be the reference group for the co-authors number and affiliation dummies. Standard errors are given in parentheses, and P-values less than 0.10, 0.05 and 0.01 are respectively denoted by $* * *$ and $* * *$. 
Table 7. Quality-productivity equation.

\begin{tabular}{|c|c|c|c|c|c|}
\hline VARIABLES & $\begin{array}{c}\text { PR(FR) } \\
\text { Heckman }\end{array}$ & $\begin{array}{c}\text { MCF(FR) } \\
\text { OLS }\end{array}$ & $\begin{array}{c}\mathrm{PO}(\mathrm{IT}) \\
\text { Heckman }\end{array}$ & $\begin{array}{c}\text { PA(IT) } \\
\text { Heckman }\end{array}$ & $\begin{array}{c}\text { RU(IT) } \\
\text { OLS }\end{array}$ \\
\hline Quantity before promotion & $\begin{array}{l}0.37^{* * *} \\
(0.026)\end{array}$ & $\begin{array}{l}0.21^{* * *} \\
(0.026)\end{array}$ & $\begin{array}{l}0.30^{* * *} \\
(0.025)\end{array}$ & $\begin{array}{l}0.18^{* * *} \\
(0.026)\end{array}$ & $\begin{array}{l}0.21^{* * *} \\
(0.029)\end{array}$ \\
\hline Quality before promotion & $\begin{array}{l}0.34^{* * *} \\
(0.027)\end{array}$ & $\begin{array}{l}0.14^{* * *} \\
(0.019)\end{array}$ & $\begin{array}{l}0.15^{* * *} \\
(0.025)\end{array}$ & $\begin{array}{c}0.093^{* * *} \\
(0.024)\end{array}$ & $\begin{array}{l}0.11^{* * *} \\
(0.030)\end{array}$ \\
\hline Co-authors quantity & $\begin{array}{c}-0.057^{* *} \\
(0.025)\end{array}$ & $\begin{array}{c}0.067^{* * *} \\
(0.024)\end{array}$ & $\begin{array}{l}-0.027 \\
(0.022)\end{array}$ & $\begin{array}{c}-0.053^{* *} \\
(0.026)\end{array}$ & $\begin{array}{c}-0.083^{* * *} \\
(0.032)\end{array}$ \\
\hline Co-authors quality & $\begin{array}{l}0.19^{* * *} \\
(0.034)\end{array}$ & $\begin{array}{l}0.20^{* * *} \\
(0.033)\end{array}$ & $\begin{array}{l}0.25^{* * *} \\
(0.031)\end{array}$ & $\begin{array}{l}0.25^{* * *} \\
(0.036)\end{array}$ & $\begin{array}{l}0.20^{* * *} \\
(0.047)\end{array}$ \\
\hline Co-authors zero Dummy & $\begin{array}{l}0.14^{* *} \\
(0.071)\end{array}$ & $\begin{array}{l}0.32^{* * *} \\
(0.070)\end{array}$ & $\begin{array}{l}0.21^{* * *} \\
(0.067)\end{array}$ & $\begin{array}{l}0.20^{* * *} \\
(0.074)\end{array}$ & $\begin{array}{c}0.052 \\
(0.099)\end{array}$ \\
\hline Large Project Dummy & $\begin{array}{l}1.04^{* * *} \\
(0.066)\end{array}$ & $\begin{array}{l}0.96^{* * *} \\
(0.061)\end{array}$ & $\begin{array}{l}1.24^{* * *} \\
(0.044)\end{array}$ & $\begin{array}{l}1.18^{* * *} \\
(0.041)\end{array}$ & $\begin{array}{l}0.95^{* * *} \\
(0.059)\end{array}$ \\
\hline Small Project with Foreign co-authors Dummy & $\begin{array}{l}0.84^{* * *} \\
(0.031)\end{array}$ & $\begin{array}{l}0.71^{* * *} \\
(0.024)\end{array}$ & $\begin{array}{l}1.04^{* * *} \\
(0.039)\end{array}$ & $\begin{array}{l}0.88^{* * *} \\
(0.032)\end{array}$ & $\begin{array}{l}0.73^{* * *} \\
(0.047)\end{array}$ \\
\hline Small project with only National co-authors Dummy & $\begin{array}{l}0.61^{* * *} \\
(0.032)\end{array}$ & $\begin{array}{l}0.43^{* * *} \\
(0.025)\end{array}$ & $\begin{array}{l}0.72^{* * *} \\
(0.039)\end{array}$ & $\begin{array}{l}0.58^{* * *} \\
(0.031)\end{array}$ & $\begin{array}{l}0.46^{* * *} \\
(0.045)\end{array}$ \\
\hline $\begin{array}{l}\text { Small Project with co-authors of unknown affiliations } \\
\text { Dummy }\end{array}$ & $0.47^{* * *}$ & $0.28^{* * *}$ & $0.49^{* * *}$ & $0.38^{* * *}$ & $0.35^{* * *}$ \\
\hline & $(0.047)$ & $(0.038)$ & $(0.084)$ & $(0.064)$ & $(0.093)$ \\
\hline Wave 1985 (FR)/ Wave 1980 (IT) & $\begin{array}{l}0.075^{* *} \\
(0.032)\end{array}$ & $\begin{array}{c}-0.0039 \\
(0.026)\end{array}$ & $\begin{array}{l}-0.028 \\
(0.030)\end{array}$ & $\begin{array}{c}0.024 \\
(0.032)\end{array}$ & $\begin{array}{c}-0.18^{* * *} \\
(0.061)\end{array}$ \\
\hline Gender & $\begin{array}{c}-0.15^{* * *} \\
(0.039)\end{array}$ & $\begin{array}{l}-0.11^{* * *} \\
(0.019)\end{array}$ & $\begin{array}{c}0.021 \\
(0.042)\end{array}$ & $\begin{array}{l}-0.019 \\
(0.027)\end{array}$ & $\begin{array}{c}-0.10^{* * *} \\
(0.028)\end{array}$ \\
\hline Age group 1 & & $\begin{array}{l}0.16^{* *} \\
(0.069)\end{array}$ & & & $\begin{array}{l}-0.085 \\
(0.20)\end{array}$ \\
\hline Age group 3 & $\begin{array}{l}-0.16^{* *} \\
(0.063)\end{array}$ & $\begin{array}{c}-0.090^{* * *} \\
(0.031)\end{array}$ & $\begin{array}{l}-0.17 \\
(0.11)\end{array}$ & $\begin{array}{l}-0.037 \\
(0.043)\end{array}$ & $\begin{array}{l}-0.065 \\
(0.042)\end{array}$ \\
\hline Age group 4 & $\begin{array}{l}-0.22^{* * *} \\
(0.081)\end{array}$ & $\begin{array}{l}-0.11^{* *} \\
(0.044)\end{array}$ & $\begin{array}{c}-0.34^{* * *} \\
(0.12)\end{array}$ & $\begin{array}{l}-0.15^{* * *} \\
(0.055)\end{array}$ & $\begin{array}{c}-0.27^{* * *} \\
(0.074)\end{array}$ \\
\hline Age group 5 & $\begin{array}{c}-0.27^{* * *} \\
(0.088)\end{array}$ & $\begin{array}{l}-0.059 \\
(0.064)\end{array}$ & $\begin{array}{c}-0.45^{* * *} \\
(0.13)\end{array}$ & $\begin{array}{c}-0.31^{* * *} \\
(0.061)\end{array}$ & $\begin{array}{c}-0.55^{* * *} \\
(0.15)\end{array}$ \\
\hline Field 30 (FR)/Fis01 (IT) & $\begin{array}{c}0.029 \\
(0.020)\end{array}$ & $\begin{array}{c}0.076^{* * *} \\
(0.017)\end{array}$ & $\begin{array}{l}-0.15^{* * *} \\
(0.023)\end{array}$ & $\begin{array}{c}-0.071^{* * *} \\
(0.026)\end{array}$ & $\begin{array}{c}-0.081^{* * *} \\
(0.032)\end{array}$ \\
\hline Field Fis02 (IT) & & & $\begin{array}{c}-0.094^{* * *} \\
(0.025)\end{array}$ & $\begin{array}{c}-0.073^{* *} \\
(0.031)\end{array}$ & $\begin{array}{l}-0.018 \\
(0.035)\end{array}$ \\
\hline Constant & $\begin{array}{l}-0.013 \\
(0.24)\end{array}$ & $\begin{array}{r}-0.070 \\
(0.85)\end{array}$ & $\begin{array}{l}-0.23 \\
(0.18)\end{array}$ & $\begin{array}{l}-0.13 \\
(0.13)\end{array}$ & $\begin{array}{c}0.13 \\
(0.32)\end{array}$ \\
\hline rho & -0.25 & & -0.15 & 0.052 & \\
\hline lambda & $-0.20^{* * *}$ & & $-0.11^{* *}$ & 0.040 & \\
\hline standard error lambda & $(0.081)$ & & $(0.052)$ & $(0.052)$ & \\
\hline Observations & 14094 & 12057 & 14114 & 12165 & 5106 \\
\hline Uncensored observation & 9018 & & 8332 & 8089 & \\
\hline Censored observations & 5076 & & 5782 & 4076 & \\
\hline Number of physicists & 705 & 1211 & 588 & 618 & 511 \\
\hline Sigma & 0.81 & & 0.76 & 0.78 & \\
\hline R-squared & & 0.288 & & & 0.402 \\
\hline
\end{tabular}

See Table 4 for the precise definitions of the variables. We control for the (year)x(cohort of entry) interactions dummies, for the Zero after promotion dummy variable and for the promotion before 1975 dummy variable, all three not reported in the Table. The Zero in preceding years is normalized to be the reference group for theco-authors number and affiliation dummies. Standard errors are given in parentheses, and P-values less than 0.10, 0.05 and 0.01 are respectively denoted $b y^{*},{ }^{* *}$ and ${ }^{* * *}$. 
Appendix Tables 
Appendix Table 1: Summary statistics of dependent and explanatory variables in promotion equations

\begin{tabular}{|c|c|c|c|c|c|c|c|c|c|c|c|c|}
\hline & \multicolumn{4}{|c|}{ PR (obs. 14094) } & \multicolumn{4}{|c|}{ PO (obs. 14114) } & \multicolumn{4}{|c|}{ PA (obs. 12165) } \\
\hline & 芯 & ర్ &.$\Xi$ & 恡 & 苂 & T & 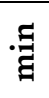 & 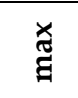 & 苂 & ర్ & : & 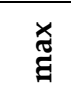 \\
\hline Promotion & 0.64 & 0.48 & 0 & 1 & 0.59 & 0.49 & 0 & 1 & 0.66 & 0.47 & 0 & 1 \\
\hline Quality flow & 0.87 & 0.61 & 0 & 4.01 & 1.21 & 0.71 & 0 & 3.78 & 0.97 & 0.74 & 0 & 3.65 \\
\hline Quantity flow & 1.42 & 0.75 & 0 & 3.00 & 1.72 & 0.70 & 0 & 3.16 & 1.46 & 0.81 & 0 & 3.02 \\
\hline Zero flow & 0.14 & 0.35 & 0 & 1 & 0.08 & 0.27 & 0 & 1 & 0.16 & 0.36 & 0 & 1 \\
\hline Academics per year & 26.97 & 15.84 & 0 & 55 & 19.12 & 29.40 & 0 & 109 & 22.24 & 30.21 & 0 & 166 \\
\hline $\begin{array}{l}\text { Wave } 1985 \text { (FR)/ } \\
\text { Wave } 1980 \text { (IT) }\end{array}$ & 0.10 & 0.30 & 0 & 1 & 0.12 & 0.32 & 0 & 1 & 0.35 & 0.48 & 0 & 1 \\
\hline Gender & 0.07 & 0.25 & 0 & 1 & 0.06 & 0.25 & 0 & 1 & 0.15 & 0.35 & 0 & 1 \\
\hline Age group 1 & 0.01 & 0.08 & 0 & 1 & 0.00 & 0.07 & 0 & 1 & 0.01 & 0.09 & 0 & 1 \\
\hline Age group 3 & 0.38 & 0.49 & 0 & 1 & 0.35 & 0.48 & 0 & 1 & 0.37 & 0.48 & 0 & 1 \\
\hline Age group 4 & 0.29 & 0.45 & 0 & 1 & 0.32 & 0.47 & 0 & 1 & 0.23 & 0.42 & 0 & 1 \\
\hline Age group 5 & 0.06 & 0.23 & 0 & 1 & 0.16 & 0.37 & 0 & 1 & 0.08 & 0.27 & 0 & 1 \\
\hline Field 30 (FR) & 0.30 & 0.46 & 0 & 1 & & & & & & & & \\
\hline Fis01 (IT) & & & & & 0.52 & 0.50 & 0 & 1 & 0.62 & 0.49 & 0 & 1 \\
\hline Fis02 (IT) & & & & & 0.23 & 0.42 & 0 & 1 & 0.18 & 0.38 & 0 & 1 \\
\hline $\begin{array}{l}\text { Promotion before } \\
1975\end{array}$ & 0.02 & 0.14 & 0 & 1 & 0.05 & 0.22 & 0 & 1 & & & & \\
\hline
\end{tabular}


Appendix Table 2: Summary statistics of dependent and explanatory variables in productivity equation for France

\begin{tabular}{|c|c|c|c|c|c|c|c|c|}
\hline & \multicolumn{4}{|c|}{ PR (obs. 9018) } & \multicolumn{4}{|c|}{ MCF (obs. 12057) } \\
\hline & ฮ్ & రే & . & 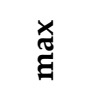 & $\underset{\Xi}{\Xi}$ & تृ & 寻 & 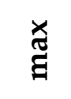 \\
\hline Productivity(Quantity) & 0.81 & 0.75 & 0 & 4.26 & 0.48 & 0.64 & 0 & 4.89 \\
\hline Productivity(Quality) & 1.21 & 0.98 & 0 & 3.19 & 0.81 & 0.98 & 0 & 3.18 \\
\hline Productivity(effort) & 0.15 & 0.14 & 0 & 0.69 & 0.09 & 0.13 & 0 & 0.69 \\
\hline $\begin{array}{l}\text { Quantity before } \\
\text { promotion }\end{array}$ & 0.81 & 0.47 & 0 & 2.82 & 0.60 & 0.44 & 0 & 2.81 \\
\hline $\begin{array}{l}\text { Quality before } \\
\text { promotion }\end{array}$ & 1.63 & 0.65 & 0 & 2.73 & 1.34 & 0.74 & 0 & 3.11 \\
\hline Co-authors quantity & 0.58 & 0.75 & 0 & 4.04 & 0.48 & 0.72 & 0 & 4.19 \\
\hline Co-authors quality & 0.84 & 0.98 & 0 & 3.11 & 0.68 & 0.95 & 0 & 3.11 \\
\hline $\begin{array}{l}\text { Co-authors zero } \\
\text { Dummy }\end{array}$ & 0.56 & 0.50 & 0 & 1 & 0.64 & 0.48 & 0 & 1 \\
\hline $\begin{array}{l}\text { Large Project Dummy } \\
\text { Small Project with }\end{array}$ & 0.02 & 0.15 & 0 & 1 & 0.02 & 0.14 & 0 & 1 \\
\hline $\begin{array}{l}\text { Foreign co-authors } \\
\text { Dummy } \\
\text { Small project with only }\end{array}$ & 0.52 & 0.50 & 0 & 1 & 0.36 & 0.48 & 0 & 1 \\
\hline $\begin{array}{l}\text { National co-authors } \\
\text { Dummy }\end{array}$ & 0.24 & 0.43 & 0 & 1 & 0.23 & 0.42 & 0 & 1 \\
\hline $\begin{array}{l}\text { Small Project with co- } \\
\text { authors of unknown } \\
\text { affiliations Dummy }\end{array}$ & 0.05 & 0.22 & 0 & 1 & 0.06 & 0.24 & 0 & 1 \\
\hline Wave 1985 (FR) & 0.13 & 0.33 & 0 & 1 & 0.20 & 0.40 & 0 & 1 \\
\hline Gender & 0.06 & 0.23 & 0 & 1 & 0.23 & 0.42 & 0 & 1 \\
\hline Age group 1 & 0.00 & 0.00 & 0 & 0 & 0.02 & 0.13 & 0 & 1 \\
\hline Age group 3 & 0.40 & 0.49 & 0 & 1 & 0.28 & 0.45 & 0 & 1 \\
\hline Age group 4 & 0.43 & 0.50 & 0 & 1 & 0.21 & 0.40 & 0 & 1 \\
\hline Age group 5 & 0.09 & 0.28 & 0 & 1 & 0.04 & 0.20 & 0 & 1 \\
\hline Field 30 (FR) & 0.29 & 0.46 & 0 & 1 & 0.34 & 0.47 & 0 & 1 \\
\hline Zeros before promotion & 0.09 & 0.29 & 0 & 1 & 0.15 & 0.36 & 0 & 1 \\
\hline Promotion before 1975 & 0.03 & 0.18 & 0 & 1 & 0.00 & 0.00 & 0 & 0 \\
\hline Zero after promotion & 0.03 & 0.18 & 0 & 1 & 0.09 & 0.28 & 0 & 1 \\
\hline
\end{tabular}


Appendix Table 3: Summary statistics of dependent and explanatory variables in productivity equation for Italy

PO (obs. 8332)

PA (obs. 8089)

RU (obs. 5106)

\begin{tabular}{|c|c|c|c|c|c|c|c|c|c|c|}
\hline "ृ & 诌 & 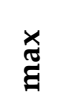 & 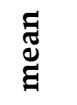 & "ृ & . & $\begin{array}{l}\text { ๕ } \\
\text { đ̆ }\end{array}$ & 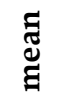 & ర్ణ & . & 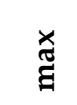 \\
\hline 0.89 & 0 & 4.36 & 0.82 & 0.88 & 0 & 4.38 & 0.94 & 0.88 & 0 & 4.43 \\
\hline 0.95 & 0 & 3.76 & 1.16 & 1.02 & 0 & 3.17 & 1.34 & 1.02 & 0 & 3.5 \\
\hline
\end{tabular}

Productivity(effort)

$\begin{array}{llll}0.15 & 0.15 & 0 & 0.69\end{array}$

$\begin{array}{llll}0.13 & 0.16 & 0 & 0.69\end{array}$

$0.13 \quad 0.15$

Quantity before

promotion

$\begin{array}{llll}1.00 & 0.59 & 0 & 3.24\end{array}$

$\begin{array}{llll}0.86 & 0.53 & 0 & 3.32\end{array}$

$0.82 \quad 0.63$

$0 \quad 3.31$

Quality before

promotion

$\begin{array}{llll}1.65 & 0.81 & 0 & 3.11\end{array}$

$\begin{array}{llll}1.52 & 0.66 & 0 & 2.80\end{array}$

$1.35 \quad 0.80$

$0 \quad 2.86$

Co-authors quantity

$\begin{array}{llll}1.06 & 0.79 & 0 & 3.50\end{array}$

$\begin{array}{llll}0.81 & 0.83 & 0 & 3.89\end{array}$

$1.00 \quad 0.85$

$\begin{array}{ll}0 & 3.43\end{array}$

Co-authors quality

$\begin{array}{llll}1.47 & 0.96 & 0 & 3.62\end{array}$

$\begin{array}{ll}1.09 & 1.03\end{array}$

$\begin{array}{ll}0 & 3.12\end{array}$

1.321 .01

$\begin{array}{ll}0 & 3.11\end{array}$

Co-authors zero

Dummy

Large Project Dummy

$\begin{array}{lll}0.28 & 0.45 & 0\end{array}$

$\begin{array}{ll}0.46 & 0.50\end{array}$

$\begin{array}{llll}0.35 & 0.48 & 0 & 1\end{array}$

Small Project with

$0.22 \quad 0.42$

$\begin{array}{ll}0.16 & 0.37\end{array}$

Foreign co-authors

Dummy

$0.48 \quad 0.50$

$0.33 \quad 0.47$

Small project with only

National co-authors

Dummy

$0.19 \quad 0.39$

0

1

$0.26 \quad 0.44$

$0.24 \quad 0.42$

Small Project with co-

authors of unknown

affiliations Dummy

Wave 1980 (IT)

Gender

Age group 1

$0.01 \quad 0.11 \quad 0$

$\begin{array}{llll}0.19 & 0.39 & 0 & 1\end{array}$

$\begin{array}{llll}0.05 & 0.21 & 0 & 1\end{array}$

$\begin{array}{llll}0.00 & 0.00 & 0 & 0\end{array}$

$\begin{array}{lll}0.02 & 0.15\end{array}$

$\begin{array}{lll}0.52 & 0.50\end{array}$

$\begin{array}{lll}0.13 & 0.34\end{array}$

$\begin{array}{llll}0.25 & 0.44 & 0 & 1\end{array}$

$\begin{array}{lll}0.00 & 0.00\end{array}$

Age group 3

Age group 4

$\begin{array}{lll}0.47 & 0.50 & 0\end{array}$

Age group 5

$\begin{array}{llll}0.27 & 0.44 & 0 & 1\end{array}$

$\begin{array}{llll}0.34 & 0.48 & 0 & 1\end{array}$

$\begin{array}{llll}0.12 & 0.33 & 0 & 1\end{array}$

$\begin{array}{llll}0.02 & 0.14 & 0 & 1\end{array}$

$\begin{array}{llll}0.49 & 0.50 & 0 & 1\end{array}$

$\begin{array}{llll}0.64 & 0.48 & 0 & 1\end{array}$

$\begin{array}{llll}0.27 & 0.44 & 0 & 1\end{array}$

$\begin{array}{llll}0.20 & 0.40 & 0 & 1\end{array}$

$\begin{array}{llll}0.34 & 0.47 & 0 & 1\end{array}$

Fis01 (IT)

Fis02 (IT)

$\begin{array}{llll}0.15 & 0.36 & 0 & 1\end{array}$

$\begin{array}{lll}0.08 & 0.27 & 0\end{array}$

$\begin{array}{llll}0.08 & 0.28 & 0 & 1\end{array}$

$\begin{array}{llll}0.00 & 0.00 & 0 & 0\end{array}$

$\begin{array}{ll}0.28 & 0.45\end{array}$

$\begin{array}{lll}0.00 & 0.06\end{array}$

$\begin{array}{llll}0.38 & 0.49 & 0 & 1\end{array}$

Zeros before promotion

Promotion before 1975

0.01

\begin{tabular}{lllllllll}
1 & 0.02 & 0.15 & 0 & 1 & 0.01 & 0.08 & 0 & 1 \\
\hline
\end{tabular}


Appendix Table 4: Two ways distribution of number of co-authors and of addresses explicitly listed in the articles.

\begin{tabular}{|c|c|c|c|c|c|c|c|c|c|c|c|c|}
\hline \multirow[t]{3}{*}{ France } & \multicolumn{4}{|c|}{ Addresses } & & & \multirow[t]{3}{*}{ Italy } & \multicolumn{4}{|c|}{ Addresses } & \\
\hline & & 6- & $11-$ & & & & & & $6-$ & $11-$ & & \\
\hline & $0-5$ & 10 & 20 & $>20$ & & & & $0-5$ & 10 & 20 & $>20$ & \\
\hline $1-5$ & 65,66 & 0,16 & & & 65,82 & & $1-5$ & 65,61 & 1,27 & 0,01 & 0,00 & 66,89 \\
\hline $6-10$ & 23,25 & 0,85 & 0,01 & & 24,11 & & $6-10$ & 15,61 & 1,86 & 0,02 & & 17,49 \\
\hline $11-20$ & 2,63 & 0,77 & 0,05 & & 3,46 & & $11-20$ & 3,21 & 1,82 & 0,15 & & 5,18 \\
\hline $21-29$ & 0,32 & 0,27 & 0,06 & 0,00 & 0,66 & & $21-29$ & 0,60 & 0,95 & 0,33 & 0,00 & 1,87 \\
\hline Large & & & & & & & Large & & & & & \\
\hline projects & 0,28 & 0,67 & 1,12 & 3,88 & 5,95 & & projects & 0,65 & 1,27 & 2,56 & 4,08 & 8,57 \\
\hline & 92,15 & 2,72 & 1,25 & 3,88 & 100,00 & & & 85,68 & 7,16 & 3,06 & 4,09 & 100,00 \\
\hline
\end{tabular}

Appendix Table 5: Average number of authors per nationality or affiliation to CERN, CNRS and CERN, for Large Project articles, based on the addresses explicitly listed.

\begin{tabular}{lllll}
\multicolumn{1}{r}{ France } & & Italy \\
\hline 1 & USA & 4.39 & USA & 2.60 \\
2 & GERMANY & 1.70 & INFN & 2.30 \\
3 & INFN & 1.28 & ITALY & 2.00 \\
4 & ENGLAND & 1.28 & GERMANY & 1.25 \\
5 & ITALY & 1.06 & ENGLAND & 1.08 \\
6 & CNRS & 0.83 & FRANCE & 0.61 \\
7 & FRANCE & 0.72 & CNRS & 0.54 \\
8 & RUSSIA & 0.51 & CERN & 0.46 \\
9 & CHINA & 0.48 & JAPAN & 0.35 \\
10 & BELGIUM & 0.41 & RUSSIA & 0.34 \\
11 & CERN & 0.31 & BELGIUM & 0.25 \\
12 & GREECE & 0.29 & SPAIN & 0.24 \\
13 & JAPAN & 0.29 & SWITZERLAND & 0.24 \\
14 & INDIA & 0.23 & CHINA & 0.22 \\
15 & NORWAY & 0.19 & GREECE & 0.21 \\
16 & SPAIN & 0.19 & NORWAY & 0.16 \\
17 & SWEDEN & 0.11 & INDIA & 0.13 \\
18 & SWITZERLAND & 0.08 & SWEDEN & 0.09 \\
19 & DENMARK & 0.07 & DENMARK & 0.08 \\
20 & CNR & 0.02 & CNR & 0.04 \\
\hline
\end{tabular}

* List limited to the 20 of most frequently cited countries or PROs. 
Appendix Table 6: Total number of articles by the French and Italian physicists in the $\mathbf{2 0}$ first journals listed in terms of decreasing numbers of articles*

\begin{tabular}{|c|c|c|c|c|c|c|}
\hline \multirow[b]{2}{*}{$\mathrm{N}$. } & \multirow[b]{2}{*}{ Journal } & \multirow[b]{2}{*}{$\begin{array}{c}\text { Entry } \\
\text { date }\end{array}$} & \multirow[b]{2}{*}{$\begin{array}{l}\text { Exit } \\
\text { date }\end{array}$} & \multicolumn{3}{|c|}{ Publications } \\
\hline & & & & Italy & France & Total \\
\hline 1 & PHYSICAL REVIEW B & 1975 & 2005 & 4225 & 3424 & 7649 \\
\hline 2 & PHYSICAL REVIEW LETTERS & 1975 & 2005 & 3000 & 2566 & 5566 \\
\hline 3 & $\begin{array}{l}\text { PHYSICS LETTERS B } \\
\text { NUCLEAR INSTRUMENTS \& METHODS IN } \\
\text { PHYSICS RESEARCH SECTION A- } \\
\text { ACCELERATORS SPECTROMETERS DETECTORS }\end{array}$ & 1975 & 2005 & 4129 & 1045 & 5174 \\
\hline 4 & AND ASSOCIATED EQUIPMENT & 1984 & 2005 & 2446 & 552 & 2998 \\
\hline 5 & JOURNAL OF APPLIED PHYSICS & 1975 & 2005 & 1245 & 1542 & 2787 \\
\hline 6 & APPLIED PHYSICS LETTERS & 1975 & 2005 & 1178 & 1347 & 2525 \\
\hline 7 & NUCLEAR PHYSICS B & 1975 & 2005 & 2039 & 308 & 2347 \\
\hline 8 & PHYSICAL REVIEW A & 1975 & 2005 & 1281 & 1036 & 2317 \\
\hline 9 & JOURNAL OF CHEMICAL PHYSICS & 1975 & 2005 & 875 & 1376 & 2251 \\
\hline 10 & PHYSICAL REVIEW D & 1975 & 2005 & 1586 & 499 & 2085 \\
\hline 11 & PHYSICAL REVIEW E & 1993 & 2005 & 1207 & 811 & 2018 \\
\hline 12 & SOLID STATE COMMUNICATIONS & 1975 & 2005 & 831 & 938 & 1769 \\
\hline 13 & JOURNAL OF PHYSICS-CONDENSED MATTER & 1989 & 2005 & 726 & 945 & 1671 \\
\hline 14 & $\begin{array}{l}\text { EUROPHYSICS LETTERS } \\
\text { JOURNAL OF MAGNETISM AND MAGNETIC }\end{array}$ & 1986 & 2005 & 778 & 858 & 1636 \\
\hline 15 & MATERIALS & 1977 & 2005 & 535 & 1060 & 1595 \\
\hline 16 & JOURNAL DE PHYSIQUE & 1975 & 1990 & 257 & 1193 & 1450 \\
\hline 17 & OPTICS COMMUNICATIONS & 1975 & 2005 & 625 & 810 & 1435 \\
\hline 18 & $\begin{array}{l}\text { JOURNAL DE PHYSIQUE IV } \\
\text { NUCLEAR INSTRUMENTS \& METHODS IN } \\
\text { PHYSICS RESEARCH SECTION B-BEAM }\end{array}$ & 1991 & 2005 & 264 & 1140 & 1404 \\
\hline 19 & INTERACTIONS WITH MATERIALS AND ATOMS & 1984 & 2005 & 731 & 652 & 1383 \\
\hline 20 & PHYSICS LETTERS A & 1975 & 2005 & 960 & 349 & 1309 \\
\hline
\end{tabular}

* The Table shows the first and last year in which we observe an article published on a journal (Entry date of the journal in the database and exit date of the journal from the database). It also gives the number of publications (Italian, French and the sum) available in the database for each journal. 